\title{
The Lower-Middle Jurassic of the Anholt borehole: implications for the geological evolution of the eastern margin of the Danish Basin
}

\author{
Ole B. Nielsen, Marit-Solveig Seidenkrantz, Niels Abrahamsen, Birthe J. Schmidt, Eva B. Koppelhus, \\ Helle Ravn-Sørensen, Uffe Korsbech and K. Gynther Nielsen
}

This study of Upper Pliensbachian - Bajocian/Bathonian deposits in a borehole drilled on the island of Anholt, Denmark incorporates sedimentology, biostratigraphy (palynomorphs and foraminifera), palaeomagnetism and coal petrology. The studied succession records a gradual change from marine inner shelf storm-influenced clays to mainly terrestrial sands, clays, and lignite containing a flora of mainly freshwater algae and pollen. The regression was initiated at the Pliensbachian-Toarcian boundary and marine influence ceased during Bajocian-Bathonian times; the regression thus took place earlier at Anholt than in the centre of the Danish Basin. The sediments in the Anholt borehole are referred to the Fjerritslev and Haldager Sand Formations. Although the Lower-Middle Jurassic boundary is commonly placed at the boundary between the two formations, our data indicate that at Anholt the upper Fjerritslev Formation (member F-IV) is of Aalenian age. The Lower-Middle Jurassic boundary occurs close to the boundary between members F-III and F-IV of the Fjerritslev Formation.

In contrast to other Lower-Middle Jurassic successions in the North Sea region, smectites of inferred volcanic origin are preserved in the Anholt section, suggesting limited burial and hence less intense diagenetic illitisation or chloritisation of smectites. A down-hole increase in diagenetic influence is reflected by the increase down-section both in the thermal stability of kaolinite and in the vitrinite reflectance. Kaolinite of inferred authigenic origin forms a white powder in the quartz-dominated sands of the Haldager Sand Formation; this kaolinite is thermally very unstable and is interpreted to be of late diagenetic, post-uplift origin. The vitrinite reflectance data indicate that the Jurassic formations have been exposed to thermal maturation corresponding to burial to a depth of 1000-1200 m below their present depth. Post-maturation uplift of the order of $1 \mathrm{~km}$ probably occurred partly during Late Cretaceous - Paleocene inversion in the Kattegat area and partly during Oligocene-Recent regional uplift, the latter being the most important of the two uplift phases. Palaeomagnetic data indicate that the main carrier of magnetic remanence is fine-grained magnetite. The stable remanence shows a pronounced inclination shallowing, which is attributed to post-depositional compaction.

Keywords: Danish Basin, Fennoscandian Border Zone, Lower-Middle Jurassic, Anholt borehole, biostratigraphy, palaeomagnetics, sedimentology, clay mineralogy, organic petrology, geochemistry

\footnotetext{
O.B.N. \& M.-S.S., Department of Earth Sciences, University of Aarbus, C.F. Møllers Allé, DK-8000 Århus C, Denmark. E-mail: geololen@aau.dk

N.A., Department of Earth Sciences, University of Aarbus, Finlandsgade 6-8, DK-8200 Arbus N, Denmark.

B.J.S., Statoil, Exploration Division, Forushagen, N-4035 Stavanger, Norway.

E.B.K., Geological Survey of Denmark and Greenland, Geocenter Copenhagen, Øster Voldgade 10, DK-1350 Copenhagen K, Denmark. Present address: Royal Tyrrell Museum of Palaeontology, Box 7500, Drumbeller TOJ OYO, Alberta, Canada. H.R.-S., Samfundsteknik A/S, Vesterballevej 4-6, Fredericia Miljøcenter, DK-700O Fredericia, Denmark. Present address: Bascon A/S, Åboulevarden 21, P.O. Box 510, DK-8100 Arbus C, Denmark.

U.K. \& K.G.N.*, Ørsted-DTU, Building 327, Technical University of Denmark, DK-2800 Lyngby, Denmark. *Retired.
} 


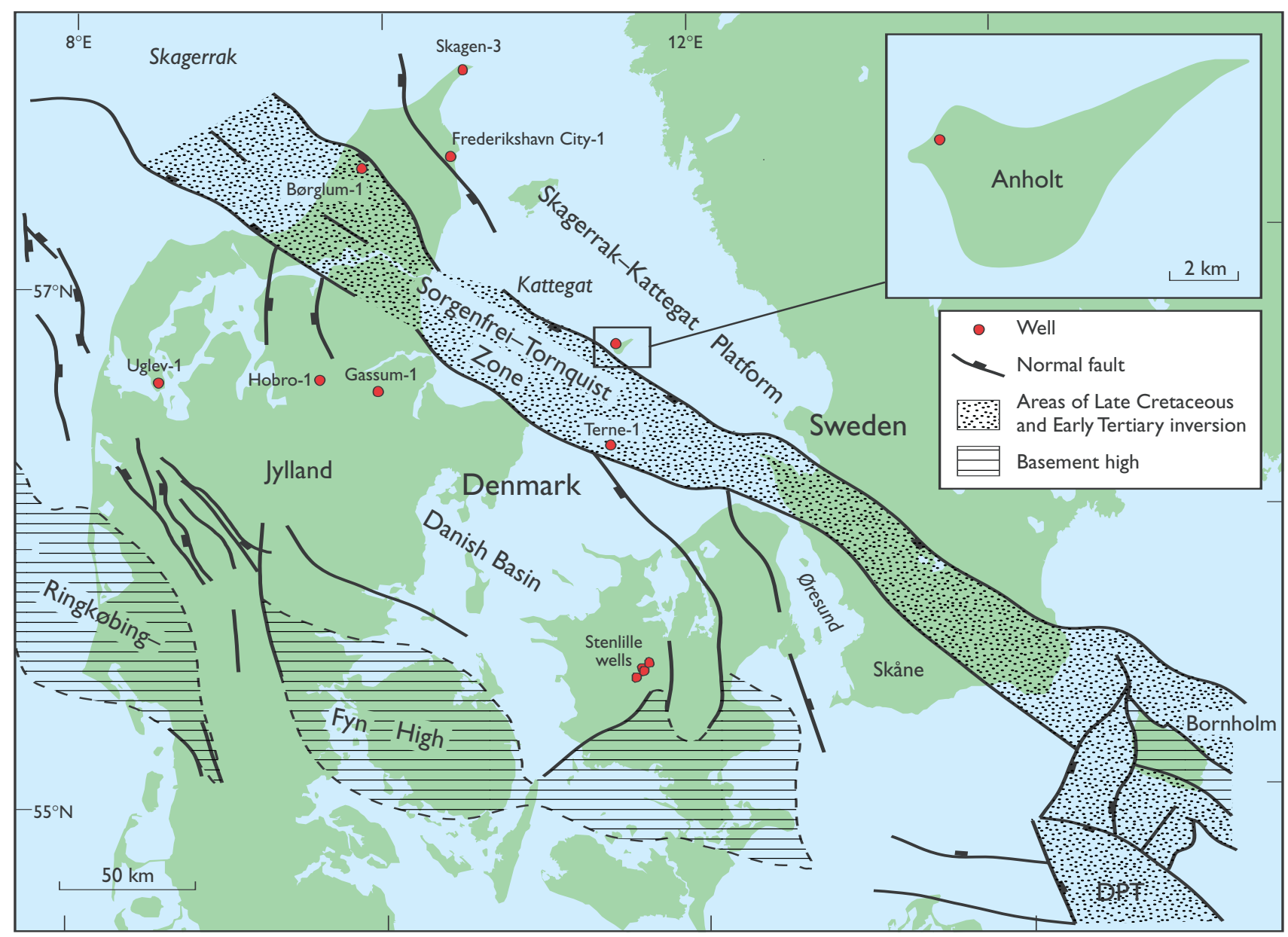

Fig. 1. Map showing the structural outline of the Fennoscandian Border Zone (Sorgenfrei-Tornquist Zone and Skagerrak-Kattegat Platform) and the Danish Basin, and the location of boreholes and outcrops mentioned in the text (structural outline from Petersen et al. 2003, this volume). The inset map of Anholt shows the location of the investigated borehole. DPT, Danish-Polish Trough.

During Early and Middle Jurassic times, a major depositional basin, the Danish Basin, extended across most of Denmark and into the modern North Sea. It was demarcated by the Baltic Shield to the north and northeast and by the Ringkøbing-Fyn High to the south, and was linked with the Danish-Polish Trough to the southeast (Sorgenfrei \& Buch 1964; Michelsen 1978; Liboriussen et al. 1987). Previous studies have shown that the upper part of the Lower Jurassic Fjerritslev Formation was characterised by a transgressive phase followed by a regressive phase, from open marine conditions during the Pliensbachian - Early Toarcian to a more restricted marine setting during the Late Toarcian (Michelsen 1978, 1989a). During the Middle Jurassic, the prograding deltaic or braided river sediments of the Haldager Sand Formation were deposited in the northeastern part of the basin (Michelsen 1978, 1989b; Koch 1983; Michelsen et al. 2003, this volume).
This study presents a Lower-Middle Jurassic section from a $306 \mathrm{~m}$ deep borehole, drilled in 1990 on Anholt, a small Danish island in the centre of the Kattegat (Fig. 1). During the Jurassic, Anholt was situated near the eastern margin of the Danish Basin. A composite section was attained by means of three boreholes, Anholt II, III, and IV, spaced less than $20 \mathrm{~m}$ apart. Only the latter two extended into Jurassic sediments. The boreholes penetrated $104 \mathrm{~m}$ of Quaternary sediments before reaching the Jurassic. The drilling site has an elevation of about $2 \mathrm{~m}$ above present-day sea level. All depths noted are referred to this point.

The aims of the study were to evaluate the age, the palaeoenvironmental setting and the post-depositional history of the Jurassic succession. To achieve this goal, studies were carried out in biostratigraphy, sedimentology, coal petrography, and palaeomagnetism. The material from 104-230 m consists largely of ditch cut- 
Fig. 2. Chronostratigraphy, biostratigraphical zonation, total organic carbon (TOC) content, and reworked palynomorphs of the lower $200 \mathrm{~m}$ of the Anholt borehole (slightly modified from Seidenkrantz et al. 1993). Quat., Quaternary; m b.s., metres below surface.

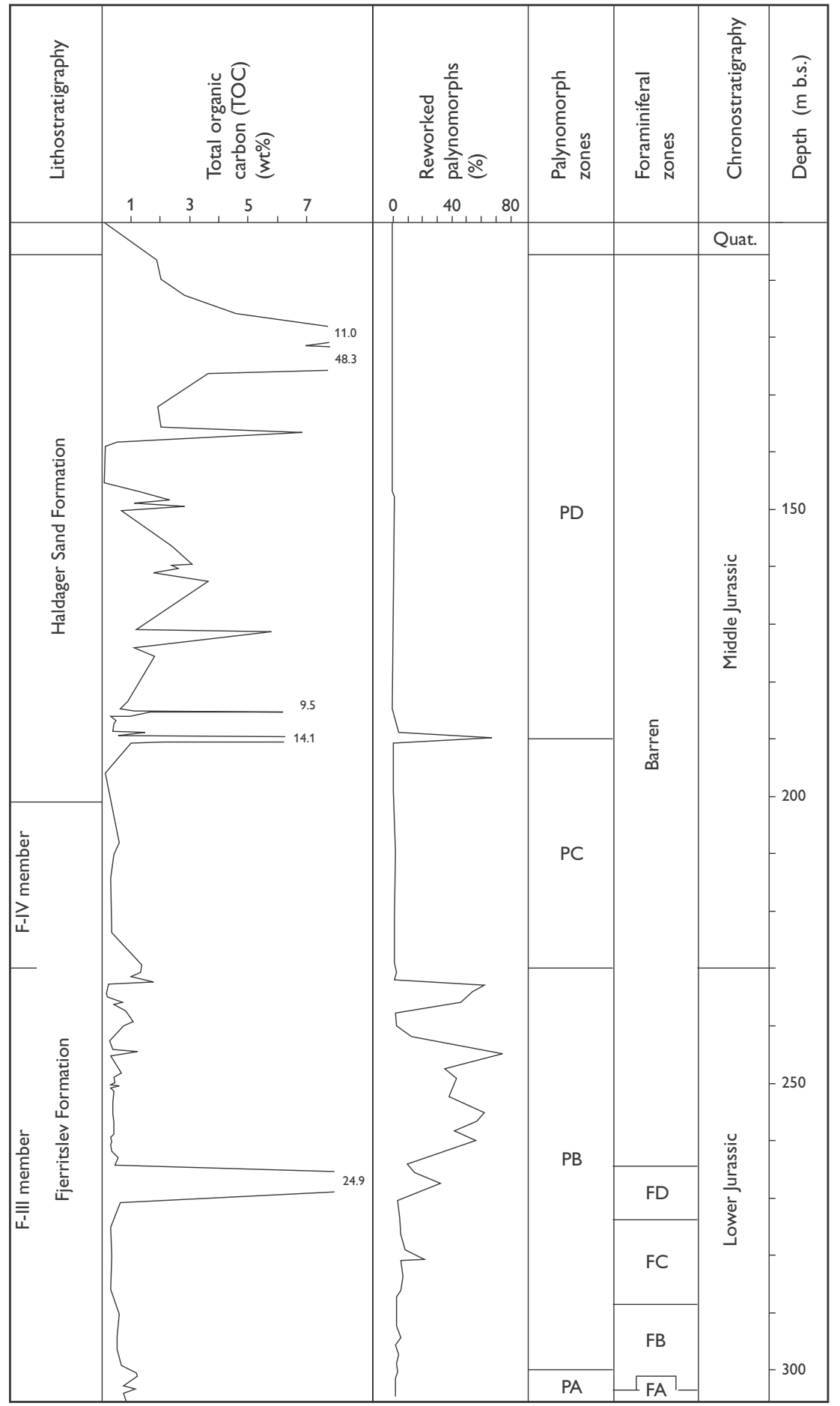

tings, together with the few available core samples, whereas the samples from below $230 \mathrm{~m}$ are all core samples (Fig. 2). Below $250 \mathrm{~m}$, core recovery was almost $100 \%$, whereas the interval above $250 \mathrm{~m}$ is only represented by few, incomplete cores. The latter cores seem mainly to represent clay or silt-rich lithologies, whereas levels with sand are less commonly represented, and primary sedimentary structures might have been destroyed. In ditch cuttings samples, the proportion of clay-sized particles is probably under-represented, as part of the only slightly consolidated clay-rich layers was incorporated with the drilling fluid during coring. 


\section{Biostratigraphy}

The age of the sediments is based on the biostratigraphical analysis. This part of the study has been previously reported in detail (Seidenkrantz et al. 1993) and here we only present a synopsis of that study. The preparation of the samples was undertaken using standard techniques (Meldgaard \& Knudsen 1979; Dybkjær 1988; Poulsen et al. 1990) and the analysis resulted in the establishment of four palynological and four benthic foraminiferal zones (Fig. 2).

\section{Microfauna}

Foraminifera are only present in the lower part of the section and cannot be correlated with faunas from other deposits in the region. With the exception of the lowermost zone (FA), the assemblages almost exclusively consist of agglutinated species (Seidenkrantz et al. 1993), whereas Jurassic foraminiferal assemblages in surrounding areas are dominated by calcareous species, mainly nodosarids (Nørvang 1957; Bang 1968a, b, 1971, 1973; Norling 1972). In general, the foraminiferal assemblages have a very low diversity and several samples are barren. The lower foraminiferal zone (FA) mainly contains nodosarid genera such as Astacolus and Planularia. The deposit also contains ammonite fragments, bivalves, and gastropods. In contrast, Zone FB $(304-288 \mathrm{~m})$ is dominated by the agglutinated genera Ammobaculites, Bulbobaculites, Kutsevella, and Haplophragmoides. The fauna of Zone FC is essentially restricted to one species of Ammobaculites, whereas Zone FD yields Ammobaculites, Bulbobaculites and a few Kutsevella (Seidenkrantz et al. 1993). The foraminifera are of a Boreal affinity not previously found this far to the south (Nagy \& Seidenkrantz in press).

\section{Palynology}

The palynomorph assemblages allow close correlation to other sections from Denmark, Germany, and Britain (Fig. 3; Schulz 1967; Lund 1977; Bertelsen 1979; Woollam \& Riding 1983; Hoelstad 1985; Dybkjær 1991; Riding \& Thomas 1992; Koppelhus \& Nielsen 1994; Koppelhus \& Batten 1996).

\section{Palynomorph Zone PA}

Based on the presence of Nannoceratopsis spp., Luehnda spinosa Morgenroth 1970, and Mendicodium reticulatum Morgenroth 1970 . This assemblage correlates well with Zone $\mathrm{C}_{3}$ in the Hobro-1 borehole in central Jylland (Bertelsen 1979) and the top of the Cerebrocellenites macrooverrucosus Zone in the Gassum-1 borehole in central Jylland (Dybkjær 1991) from the Danish Basin and with the Luehndea spinosa Zone in the British part of the North Sea (Riding \& Thomas 1992). Further possible correlations are with the Luebnda spinosa Zone and the uppermost Chasmatosporites Zone, both from the Bagå Formation of Bornholm (Koppelhus \& Nielsen 1994) in the Danish-Polish Trough and from the Rya Formation in the Øresund area (Fig. 3; Koppelhus \& Batten 1996). Recent palynological study of the Neill Klinter Group, Jameson Land, East Greenland (Koppelhus \& Dam 2003, this volume) permits correlation of Zone PA from Anholt with Assemblage Zone 2 of the Neill Klinter Group at the Albuen section. The combined evidence suggests a Late Pliensbachian age for Zone PA.

\section{Palynomorph Zone PB}

Based on the acme of Spheripollenites together with Corollina, Ischyosporites variegatus (Couper) Schulz 1967 and Manumia delcourtii (Pocock) Dybkjær 1991. The zone is correlated with Zone $\mathrm{C}_{4}$ from the Hobro-1 borehole (Bertelsen 1979) and the SpheripollenitesLeptolepidites Zone in the Stenlille boreholes (Dybkjær 1991) of the Danish Basin. It can also be correlated with Zone I of the Bagå Formation (Hasle Klinkerfabrik clay pit of Bornholm; Hoelstad 1985) and the Nannoceratopsis gracilis and Spheripollenites-Leptolepidites Zones from the Bagå Formation (Korsodde section, Bornholm; Koppelhus \& Nielsen 1994) in the DanishPolish Trough. The Spheripollenites-Leptolepidites Zone is also known from the Rya Formation in the Øresund area (Koppelhus \& Batten 1996) and from Assemblage Zone 5 in the Neill Klinter Group in East Greenland (Koppelhus \& Dam 2003, this volume). The age is considered to be Toarcian.

\section{Palynomorph Zone PC}

Based on abundant Perinopollenites elatoides Couper 1958 together with Callialasporites turbatus (Balme) 


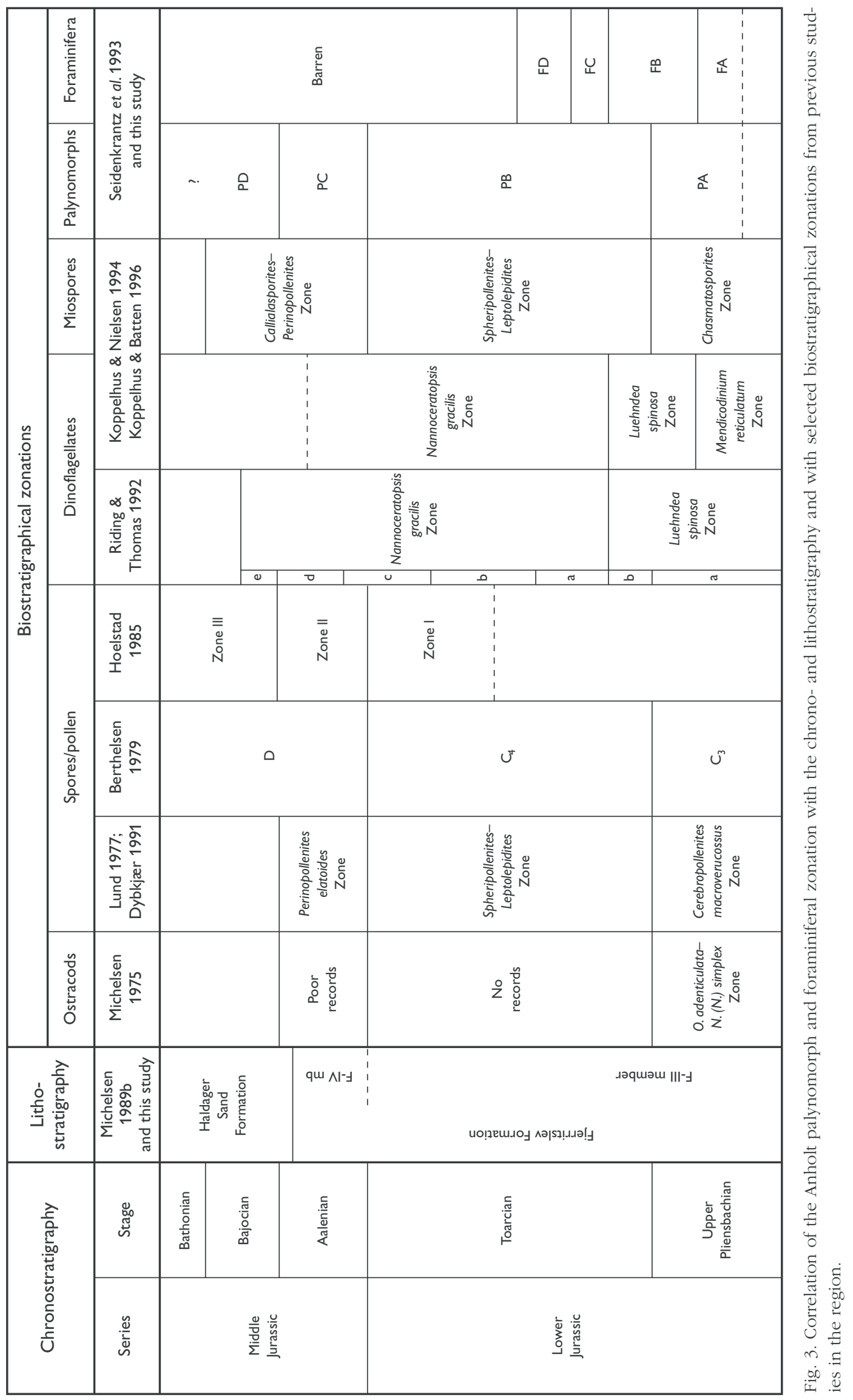


Dev 1961, Nannoceratopsis gracilis Alberti emend. van Helden 1977, and Nannoceratopsis senex van Helden 1977. This palynomorph assemblage correlates with the Perinopollenites elatoides Zone from the Stenlille boreholes in the Danish Basin (Dybkjær 1991), Zone II from the Bagå Formation at the Hasle Klinkerfabrik clay pit, Bornholm (Hoelstad 1985) and the lower part of the Callialasporites-Perinopollenites Zone from the Bagå Formation in Borehole 107 and the Korsodde section, Bornholm (Koppelhus \& Nielsen 1994). The zone is also recognised in the Rya Formation in the Øresund area (Fig. 3; Koppelhus \& Batten 1996) and from Assemblage Zone 6 in the Neill Klinter Group, East Greenland (Koppelhus \& Dam 2003, this volume). This correlation suggests an Aalenian age for Zone PC.

\section{Palynomorph Zone PD}

Characterised by Perinopollenites elatoides, Callialasporites turbatus, C. dampieri (Balme) Dev 1961, C. microvelatus Schulz 1966, C. minus (Tralau) Guy 1971, Densoisporites scanicus Tralau 1968, Neoraistrickia gristhorphensis (Couper) Tralau 1964, Sestrosporites pseudoalveolatus (Couper) Dettmann 1963, Gleicheniidites conspiciendus (Bolchovitina) Krutzsch 1959, and G. senonicus Ross 1949. This assemblage suggests a correlation with Zone D in Hobro-1 (Bertelsen 1979), with Zone III from the Bagå Formation (Hasle Klinkerfabrik clay pit; Hoelstad 1985), and with the upper part of the Callialasporites-Perinopollenites Zone, also from the Bagå Formation on Bornholm (Bagå beds, section 1; Koppelhus \& Nielsen 1994). The age of the assemblage is considered to be Middle Jurassic, probably within the Bajocian/Bathonian interval.

\section{Palaeomagnetic studies}

The continuous record of palaeomagnetic anomalies derived from the deep-sea record only reaches back to the late Middle Jurassic (base of M29 of the top Callovian; Harland et al. 1990). Older reversal chronology therefore relies upon palaeomagnetic polarity studies of individual stratigraphical sections (Ogg et al. 1984; Steiner et al. 1985, 1987; Gradstein et al. 1994). The aim of the present palaeomagnetic study was to contribute to the gradually increasing knowledge of reversals in Mesozoic times. This palaeomagnetic study is the first of its kind in the Danish area, as previous studies from the area focussing upon pre-Quaternary strata are few (e.g. Abrahamsen 1994; Ali et al. 1994), and none of these were from the Jurassic.

\section{Magnetic methods and results}

A total of 122 samples were collected for magnetic studies from the cored sections in Anholt III and IV. The samples were obtained by pressing one-inch cylindrical polystyrene holders into argillaceous parts of the stiff sediment. Most of the samples are from the Toarcian (78 samples), whereas 17 are from the Aalenian, and 27 are from the Bajocian/Bathonian section. All samples were routinely measured in a Molspin Ltd. spinner magnetometer and subsequently step-wise demagnetised in 5, 10, 20, and $30 \mathrm{mT}$ alternating fields (AF) (three orthogonal directions inside metal shields) and remeasured after each step.

In order to determine the carriers of the magnetic remanence, eight samples were treated in step-wise increasing pulse-magnetic fields up to $0.6 \mathrm{~T}$ (Fig. 4). The

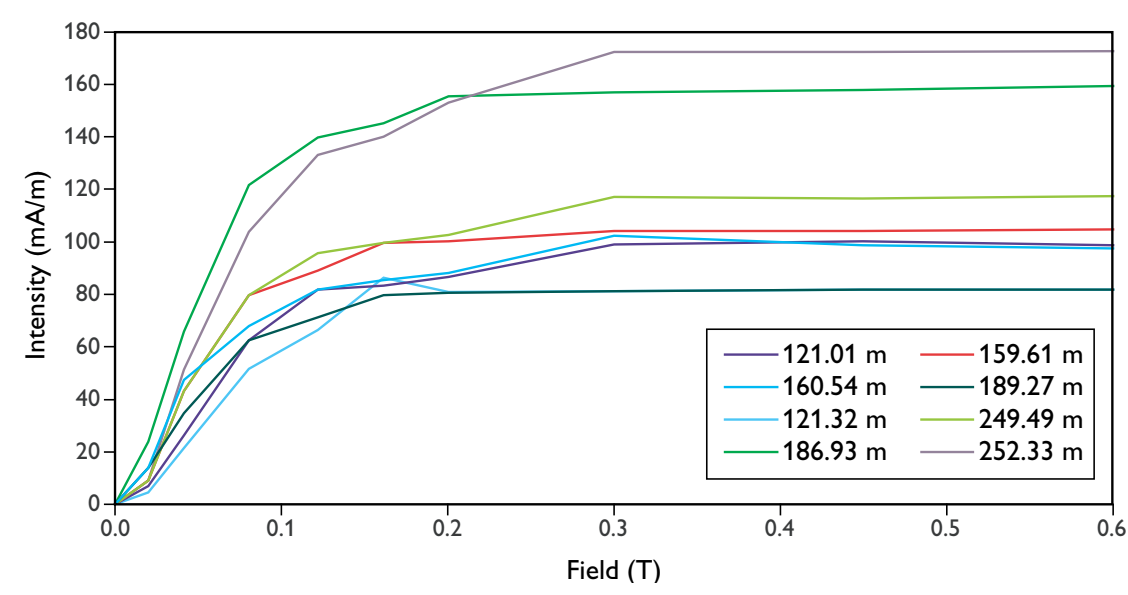

Fig. 4. IRM (isothermal remanent magnetisation) performed on eight samples, which show saturation between 0.2 and $0.3 \mathrm{~T}$, suggesting magnetite to be the carrier of the remanence. 


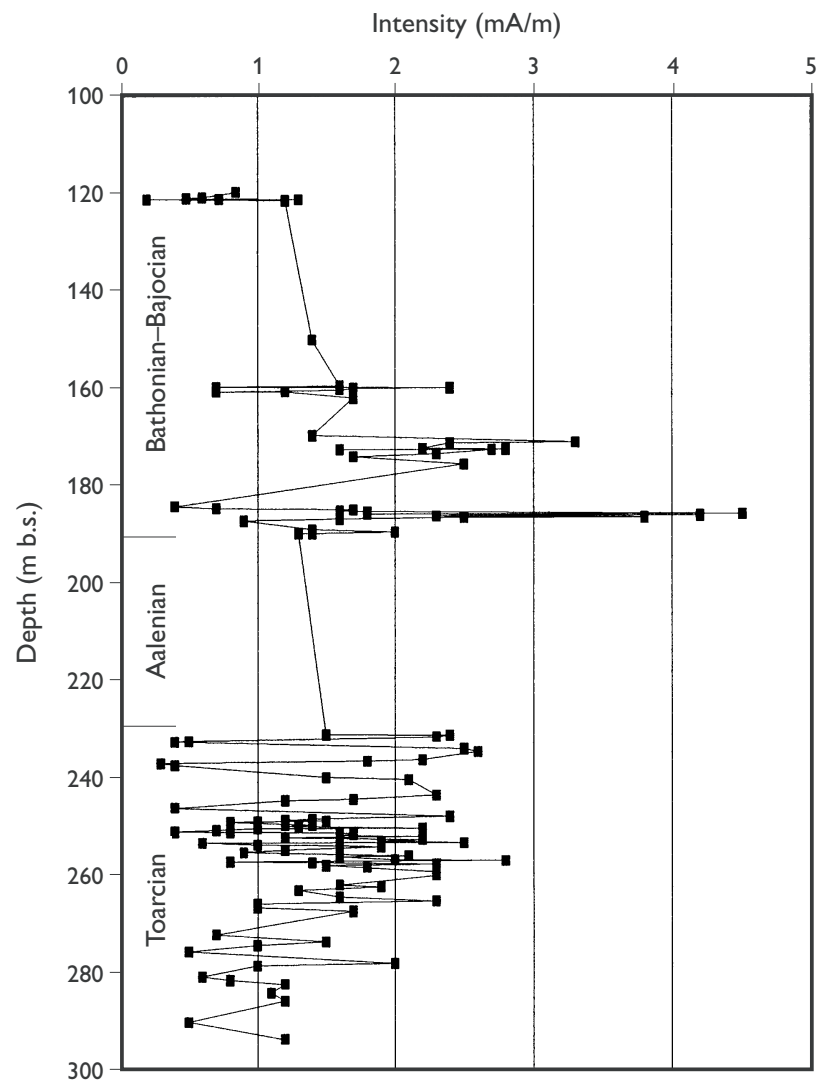

Fig. 5. NRM (natural remanent magnetisation) intensity vs. depth. Most NRM intensities are between 0.5 and $2.5 \mathrm{~mA} / \mathrm{m}$, with an average of $1.5 \mathrm{~mA} / \mathrm{m}$. m b.s., metres below surface.

IRM (induced remanent magnetisation) typically saturates in fields between 0.2 and $0.3 \mathrm{~T}$, indicating that the magnetic carriers are dominated by magnetite rather than hematite or goethite. As the MDF (median destructive field) for most samples is well above $30 \mathrm{mT}$, this suggests that the magnetic minerals are dominated by single- or pseudosingle-domain magnetites, probably of detrital origin. The NRM (natural remanent magnetisation) intensity is low, typically $1-2 \mathrm{~mA} / \mathrm{m}$, with extremes of about 0.4 and $4.5 \mathrm{~mA} / \mathrm{m}$ (Fig. 5). The magnetic declination is not known, as the cores were not oriented in azimuth. The AF cleaned inclination ( $30 \mathrm{mT}$ ) is shown in Figure 6.

The present latitude of Anholt is $56.7^{\circ} \mathrm{N}$, which is equivalent to a central axial dipole inclination of $\mathrm{I}_{0}=$ $71.8^{\circ}$. However, nearly all the inclinations are much closer to $0^{\circ}$ than expected (Fig. 6). Only 16 out of the 122 samples show inclinations more than $\pm 30^{\circ}$ from $0^{\circ}$. During the Jurassic, the Danish area had a latitudi-

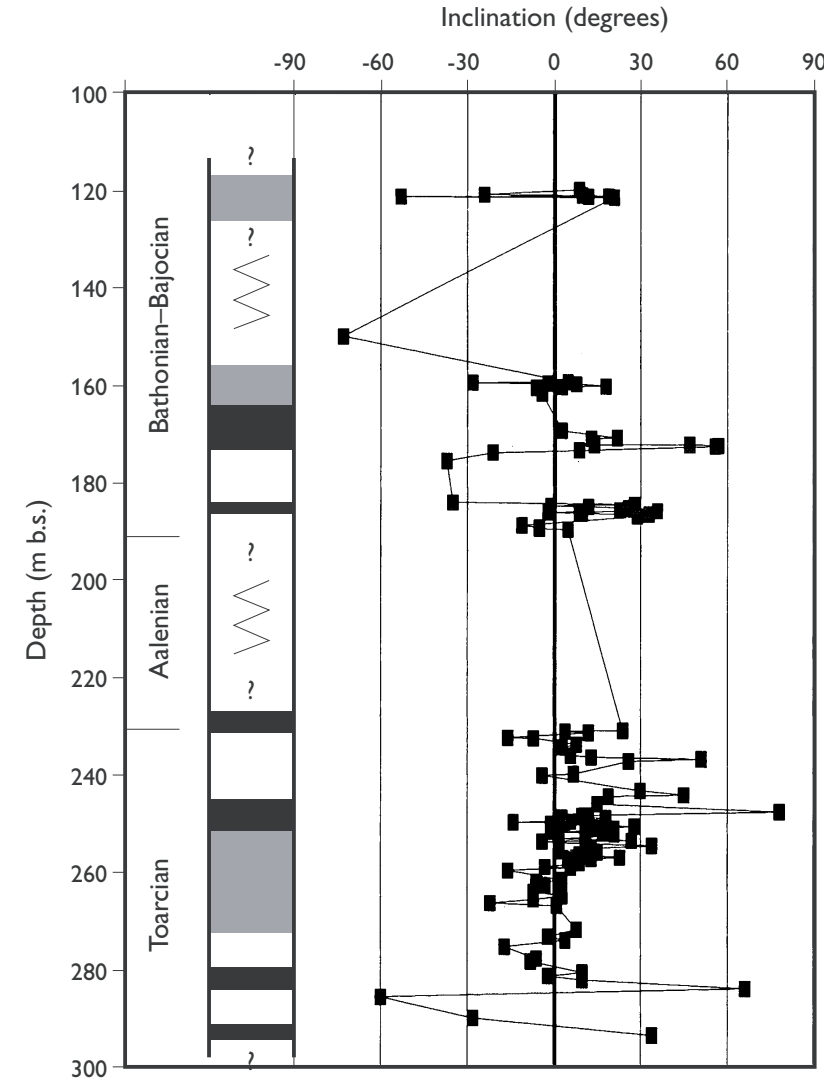

Fig. 6. Suggested polarity interpretation of the Jurassic inclination record from the Anholt borehole. Black, normal polarity; white, reversed polarity; grey, intervals in which polarity is mixed or undetermined; zigzag line, significant intervals in which polarity data is lacking; $\mathbf{m}$ b.s., metres below surface.

nal position not significantly south of today (Press \& Siever 1982), indicating that this pronounced inclination shallowing cannot be due to plate drift alone, but rather was caused by either remagnetisation or compaction (Abrahamsen 1992). As both polarities are found, secondary magnetisation is unlikely to be the cause. The inclination shallowing in the sediment is thus probably due to compaction.

On account of the presence of several major gaps in sampling caused by lithological variation (coarse-grained sections were either not recovered or not sampled for palaeomagnetic studies) as well as due to the dominant shallow inclinations, the reversal chronology based upon the material from Anholt is poorly constrained. A tentative interpretation is shown in Figure 6, but a more detailed magnetostratigraphical correlation to other palaeomagnetic records such as the detailed sequence from the Bajocian-Bathonian of south Spain (Steiner et al. 1987) is not justified at present. 


\section{Lithology}

A preliminary sediment description was performed during the drilling operation. A more detailed description was made subsequently, both of cores and cuttings samples, and black-and-white and colour photographs of the cores were taken. X-ray photographs were taken of selected $1 \mathrm{~cm}$ thick slices of the core material. Immediately after drilling, a SNG-log (Spectral Natural Gamma-ray log) was obtained from the Anholt IV borehole. Preliminary results were published by Nielsen (1992).

\section{Methods}

The following analyses were carried out:

1. Grain-size analysis using wet sieving (> $63 \mu \mathrm{m}$ fraction) and settling in Andreassen tubes $(<63 \mu \mathrm{m}$ fraction).

2. Bulk sediment geochemistry comprising TOC (total organic carbon) and sulphur analysis measured in a LECO induction furnace, as well as measurements by Atomic Absorption Spectrophotometry (AAS) of the content of the main elements: $\mathrm{Si}, \mathrm{Al}, \mathrm{Fe}, \mathrm{Ca}, \mathrm{Mg}, \mathrm{Mn}$, $\mathrm{Na}$, and $\mathrm{K}$.

3. Mineralogical composition of both bulk samples and of the clay fraction using X-ray Diffraction (XRD). Samples for bulk mineralogy were dried in a furnace at $105^{\circ} \mathrm{C}$ for 16 hours, and ground in a mortar. The powder was mounted in the sample holder without preferred orientation. Samples for clay mineralogy were dispersed in distilled water, sieved through a $63 \mu \mathrm{m}$ mesh, and the $<2 \mu \mathrm{m}$ fraction was obtained by repeated decantation in distilled water. The $<2 \mu \mathrm{m}$ fraction was smeared onto glass plates in order to obtain preferred orientation of the clay minerals. The glass plates with the clay film were $\mathrm{X}$-rayed in various conditions: air-dried, ethyleneglycol-treated and after heating to different temperatures (Nielsen et al. 1989).

4. Some of the samples were heated at a rate of $2^{\circ} \mathrm{C}$ per minute in a Differential Thermal Analysis/Thermal Gravimetry (DTA/TG) instrument in order to determine the temperatures for oxidation of organic compounds and to release the OH-groups of the phyllosilicate minerals. The change in weight from these processes was determined. The analyses were performed both on bulk samples and on the clay fractions $(0-2 \mu \mathrm{m}$,
$0-1 \mu \mathrm{m}$, and $1-2 \mu \mathrm{m})$ and were followed by heating to $468^{\circ} \mathrm{C}$. This temperature was kept constant for 8 hours and the weight loss from the release of $\mathrm{OH}_{-}$ groups as a function of time was recorded. A temperature of $468^{\circ} \mathrm{C}$ was chosen, because the DTA/TG curve indicated that approximately $465^{\circ} \mathrm{C}$ was the threshold temperature for the dehydroxylation process at the heating rate used. The time in minutes for the release of half of the OH-groups was calculated.

5. The same samples were exposed to heating in steps of $25^{\circ} \mathrm{C}$ from $450-600^{\circ} \mathrm{C}$ followed by XRD analysis in order to observe the decomposition of the crystal structure in kaolinite.

\section{Results and discussion}

\section{Sedimentary facies}

The clays and sands from 306-201 $\mathrm{m}$ are referred to the Fjerritslev Formation (Figs 2, 7; Michelsen 1978). In the lower part (c. 306-231 m), the SNG-log is rather uniform and the sediment consists of a relatively homogeneous, greyish green clay with a low median grain-size (Fig. 8). This interval is equivalent to member F-III of the Fjerritslev Formation (Michelsen 1978).

The lowermost $c .6 \mathrm{~m}$ are characterised by a slightly sandy and bioturbated clay (Figs 7, 8) with ammonites. Pure clay lithologies make up 50-70\% of each core, the remainder comprising silty clay layers and fine-grained sand laminae. Above this basal unit, the clay is commonly non-bioturbated and contains less than $1 \%$ sand, except for very thin laminae of fine-grained sand of inferred storm origin. Silty clays form between 1 and $30 \%$ of each core, whereas pure clay makes up $70-99 \%$ of each core. Upwards, especially above $260 \mathrm{~m}$, the storm sand layers become coarser and thicker, up to a few millimetres, and the sand content in the clay layers increases to 4-6\% (Fig. 8). Some sand laminae are cross-laminated.

At $231 \mathrm{~m}$, a carbonate-cemented lignite conglomerate (Fig. 9) marks the lower boundary of member F-IV of the Fjerritslev Formation (Michelsen 1978). This member continues up to $201 \mathrm{~m}$ and is characterised by sandier sediments with more numerous and thicker sand layers intercalated with the clay layers. The sand layers show an upwards increase in the content of very fine pebbles from $1.6-8.5 \%$ in the lower part to $11-23 \%$ in the upper part (Fig. 8).

The upper part of the Jurassic succession (201-104 m) is referred to the Haldager Sand Formation (Michelsen 


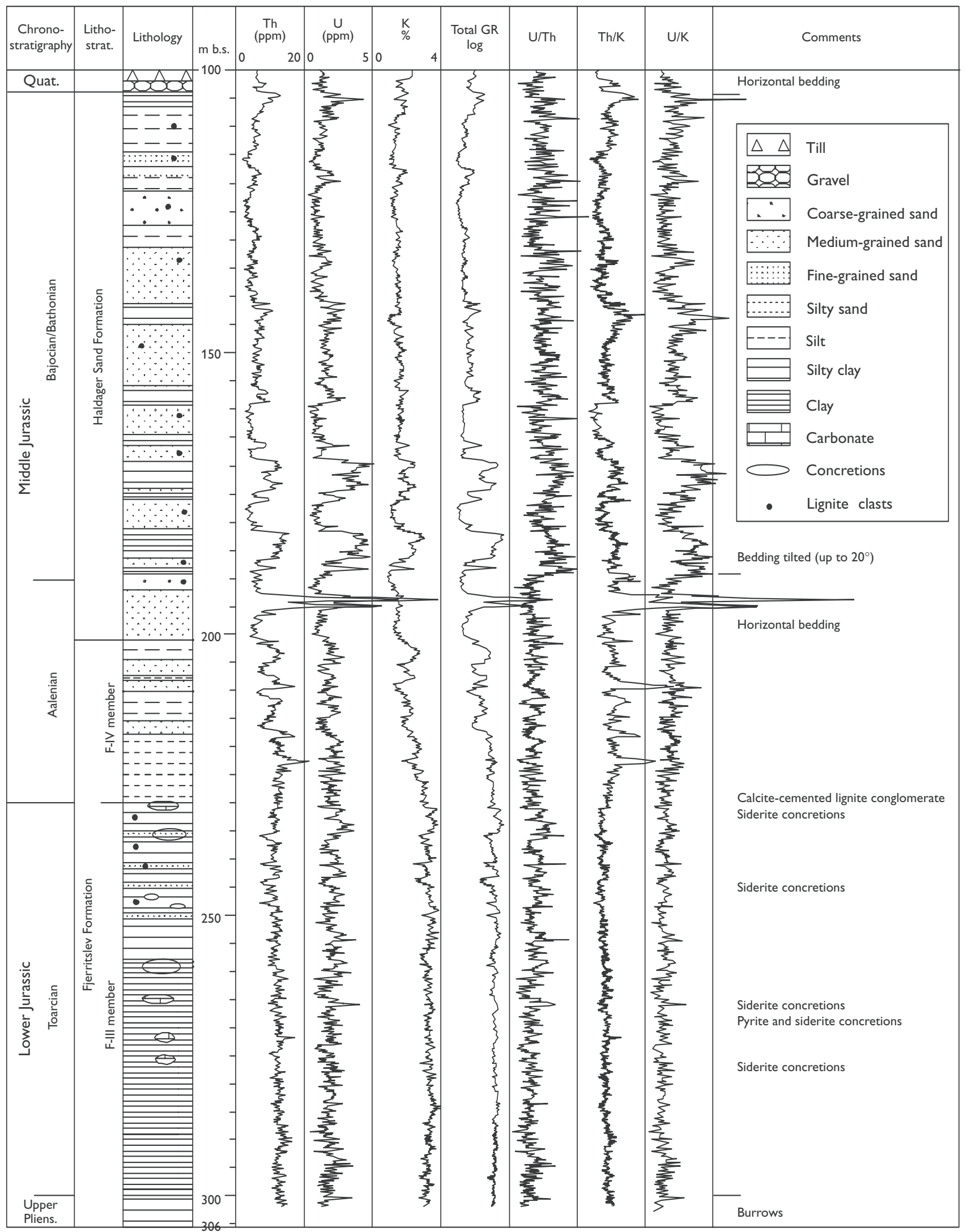

Fig. 7. Integrated log combining lithostratigraphical and lithological data with the Spectral Natural Gamma-ray log (SNG). Quat., Quaternary; Pliens., Pliensbachian; m b.s., metres below surface. 


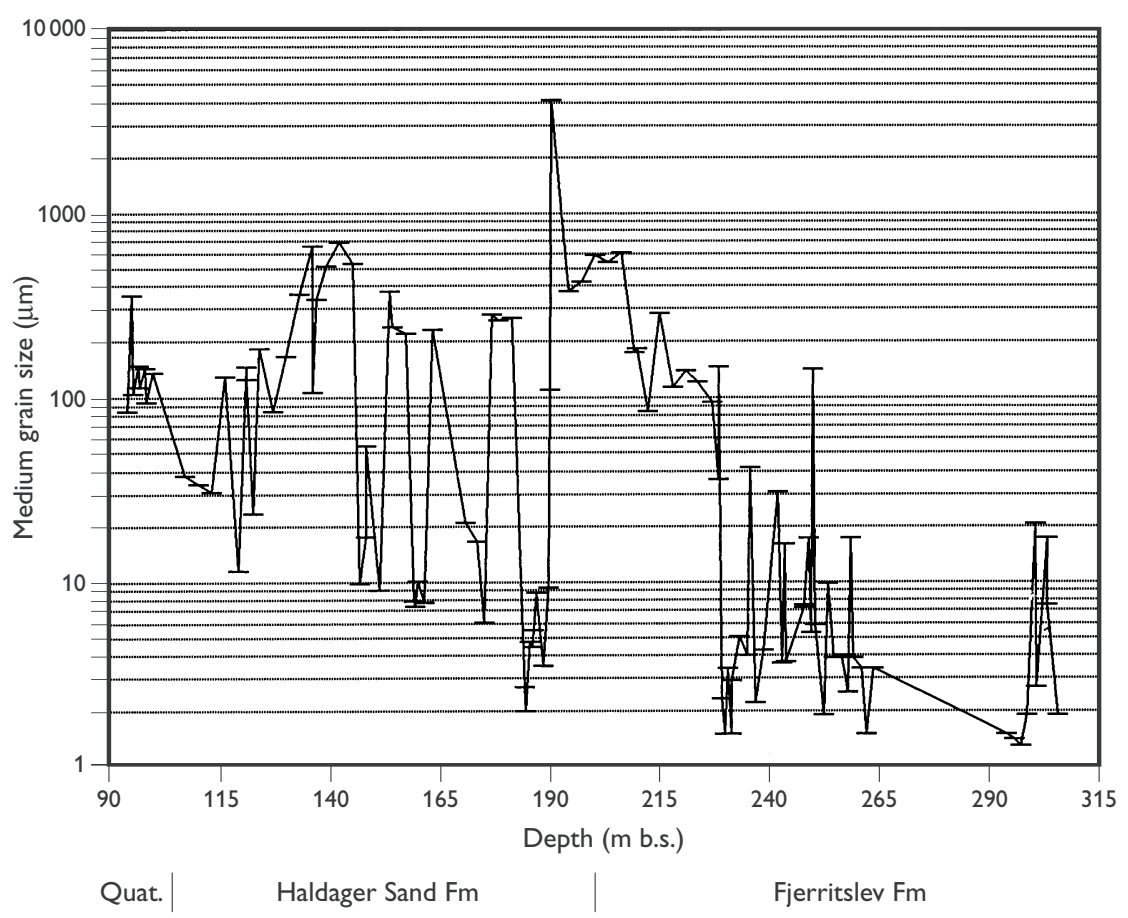

Fig. 8. Median grain-size values; note the logarithmic scale on the y-axis. Some reservations should be made concerning the results of the grain-size analysis of the F-IV member (231-201 m), as no cores were recovered from this interval. The sediments are only slightly consolidated, and the more fine-grained parts might therefore have been incorporated in the drilling fluid. $\mathbf{m}$ b.s., below surface.
1978). This part has a markedly higher content of sand with brown coal fragments. The lithology of the Haldager Sand Formation shows a cyclic variation which is also evident on the gamma-ray log (Fig. 7). Intervals (1-10 m thick) of medium-grained sand with lignite fragments alternate with $1-5 \mathrm{~m}$ thick units of silty clay with high TOC contents (Fig. 2). Lignite layers, a few centimetres thick, also occur locally. The observed variations in lithology might be explained by lateral migration of channels in a delta-plain or floodplain setting.

\section{SNG-log analysis}

The thorium (Th), uranium (U), potassium (K), and integrated gamma-ray signals from the Spectral Natural Gamma-ray log (SNG-log; Fig. 7) obtained from the Anholt IV borehole show some significant variations throughout the Jurassic section. The main carrier of potassium is believed to be phyllosilicates (clay minerals and mica), as almost no potassium feldspar was observed. Uranium is normally concentrated in layers rich in organic matter but may also be present in some heavy minerals. The Th-content is somewhat greater in kaolinite than in other clay minerals, but some heavy minerals contain relatively high concentrations of Th (see below). The log signal is very uniform in member F-III of the Fjerritslev Formation. The only exceptions are characteristic negative peaks where carbonate and pyrite concretions and sand laminae are present (Fig. 7). The lower gamma-ray values probably indicate a lower concentration of $\mathrm{Th}, \mathrm{U}$ and $\mathrm{K}$ in the carbonate concretions than in the surrounding compacted clay, suggesting that carbonate cementation took place shortly after deposition and prior to significant concentration of $\mathrm{K}$, Th and $\mathrm{U}$ due to compaction of the clays. The log signature of member F-IV is markedly different from that of the Haldager Sand Formation, mainly due to variations in lithology. The fine-grained layers are enriched in K-containing phyllosilicates and U-containing organic matter relative to the coarser layers. Part of the Th content is probably also related to kaolinite particles, which are more common in the finer size fractions.

\section{Uranium and thorium anomalies in the SNG-log}

Some thin layers in member F-IV of the Fjerritslev Formation and in the lowermost part of the Haldager Sand Formation (around $195 \mathrm{~m}$ ) have higher concentrations of Th, and to some extent also U (Fig. 7). The smaller Th and $\mathrm{U}$ anomalies are all located within the coarsening-upwards marine member F-IV, whereas the two strong anomalies are located within the lower levels of the generally non-marine Haldager Sand Formation (environmental interpretations from Michelsen 1978, 1989a). The K content is constant or even relatively low in these layers (see also the element ratios in Fig. 7). 
The base-level of the gamma-ray signal is relatively high in the clay lithologies of the Fjerritslev Formation, but considerably lower in the Haldager Sand Formation. Low gamma signals are normal for sand layers. Ditch cuttings samples and samples from the very few cores from these low gamma-ray intervals are dominated by sand thus supporting the log interpretation. However, the very poor core recovery in this section of the borehole did not allow very precise sampling of undisturbed Th-rich intervals, so the reason for the high concentrations of this element is unclear.

Similar peaks of Th and $\mathrm{U}$ are found in Jurassic, Cretaceous and Miocene deposits in other Danish boreholes (Korsbech \& Nielsen 1991; Korsbech 1992). The same phenomenon is seen in sections with excellent core recovery of Lower Cretaceous fine-grained sand in the Skagen-3 borehole. Here, the coarse silt fraction contains a considerable proportion of heavy minerals (mainly zircons; H. Friis, personal communication 1992). The same observation has been made by Conner \& Kelland (1975a, b) in a Jurassic sandstone in a North Sea well; zircons and other heavy minerals such as monazite, rutile and epidote commonly contain a substantial amount of Th, and it was suggested that this might be the source for the relatively high content of this element. The same explanation may be applicable to the Jurassic in the Anholt cores.

An examination of some older borehole logs indicates that layers enriched in heavy minerals may be a common phenomenon in Jurassic sandstones in Denmark. Although SNG-logs were not run in these old boreholes, we propose that some of the peaks observed on natural gamma-logs in the Jurassic and Lower Cretaceous sediments of the Frederikshavn City- 1 and Børglum-1 boreholes are due to a high content of heavy minerals. Larsen (1966) detected several samples with zircon contents of up to $60 \%$ of the non-opaque, nonmicaceous heavy fraction. Higher gamma signals are normally found in these layers.

The concentrations of Th and U between 198 and $190 \mathrm{~m}$ are shown on Figure 10; note that the $\mathrm{U}$ and Th peaks are displaced slightly $(5-10 \mathrm{~cm})$ relative to one another. The scales were chosen in order to equate the heights of the Th and U peaks at $193.9 \mathrm{~m}$. The ratio between the Th and $\mathrm{U}$ concentrations here is 5:1. In contrast, the Th:U ratio for the peaks at $195 \mathrm{~m}$ is about 10:1; note that minor fluctuations occur within these peaks at $195 \mathrm{~m}$. This variation in the Th:U ratio may imply that some separation of the heavy minerals has taken place, probably based on differences in grain size and density.
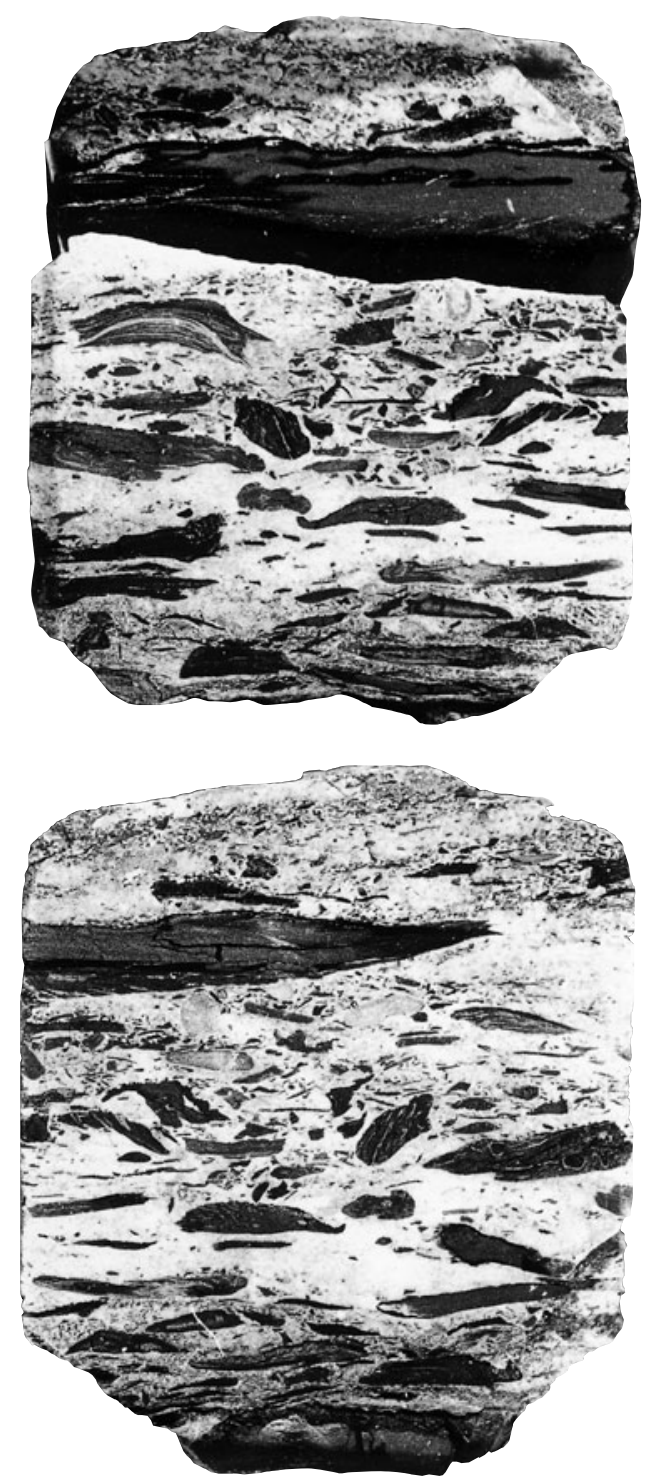

Fig. 9. Core photograph of part of the interval from 232.6-231.1 $\mathrm{m}$ b.s., Fjerritslev Formation, F-III member, uppermost Toarcian. Opposing faces of a single slabbed core piece are illustrated. The dark clasts are lignite fragments, up to $7 \mathrm{~cm}$ in length, in a matrix of calcite-cemented clayey, silty sandstone. Width of core is $10 \mathrm{~cm}$

\section{Bulk mineralogy}

The mineralogical composition of the Jurassic succession of the Anholt borehole is relatively simple; it comprises only stable, detrital minerals and a few authigenic/diagenetic minerals. The detrital minerals are quartz, clay minerals (including mica) and very little feldspar; the authigenic/diagenetic minerals are pyrite, calcite and siderite. Authigenic feldspars have been 


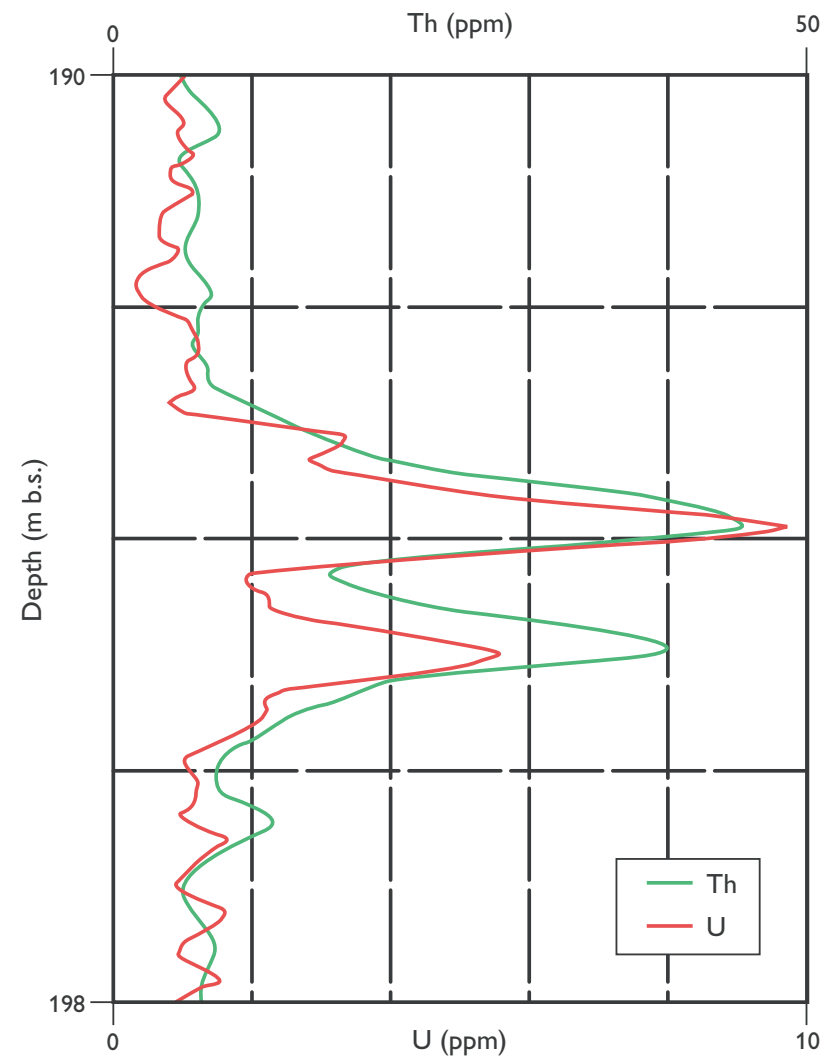

Fig. 10. Thorium (Th) and uranium (U) concentrations between 198 and $190 \mathrm{~m}$ b.s. The relative concentrations $(\mathrm{Th} / \mathrm{U})$ differ for the two peaks, probably reflecting sorting processes during sedimentation. $\mathbf{m}$ b.s., below surface. reported in Middle Jurassic sediments elsewhere in the North Sea Basin (Nielsen \& Friis 1985), but were not observed in this borehole.

The mineralogical variation mainly reflects the grainsize variation and the location of pyrite and carbonate concretions of predominantly sideritic composition. The boundary to the overlying Quaternary sediments is clearly marked by a distinct increase in feldspars and amphiboles, i.e. minerals with a relatively low resistance to chemical weathering.

\section{Clay mineralogy}

The non-clay minerals of the $<2 \mu \mathrm{m}$ fraction are dominated by quartz, but the quartz content is much lower in fractions below $1 \mu \mathrm{m}$. Chlorite is only present in small quantities with a slight tendency to decrease upwards (Fig. 11), presumably due to the diagenetic origin of this mineral. Illite is a common mineral although the measured illite content in the coarser layers is presumed to also include muscovite (identified macroscopically), as it is difficult to distinguish between these two very similar minerals by XRD. Kaolinite is the dominant clay mineral in the coarser sediments. In sands from the Haldager Sand Formation, macroscopic examination revealed a white powder, identified as pure kaolinite by XRD. In finer grades of the clay fraction, the kaolinite content is notably lower, due to its normally larger grain-size relative to other clay minerals.

Smectites are present in the lower, fine-grained layers (Figs 11, 12), but decrease in proportion up-section, rel-

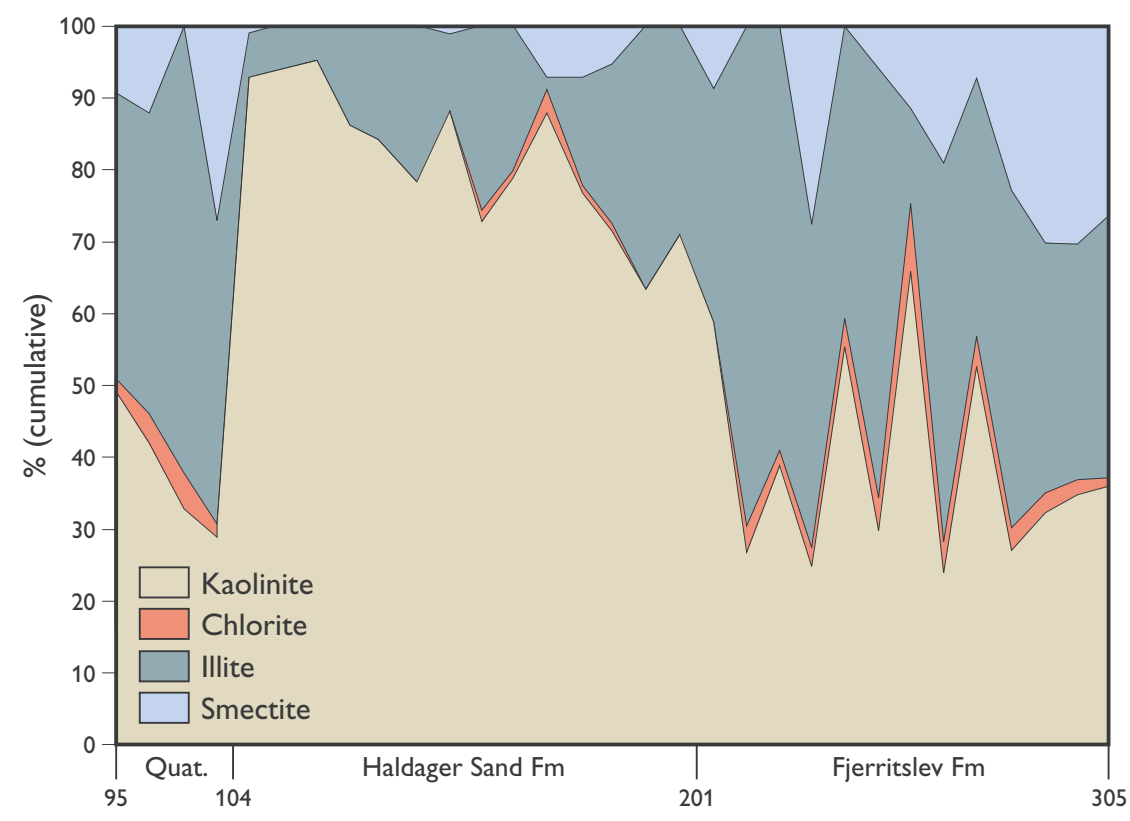

Fig. 11. Clay mineralogy of the $<2 \mu \mathrm{m}$ fraction. Sum of clay minerals $=100 \%$. The analyses are displayed in stratigraphic order but the horizontal scale is not directly proportional to depth; the depth to the main lithostratigraphic divisions is indicated (in metres below surface). 
Fig. 12. X-ray diffractogram of the clay fraction of a sample from the Fjerritslev Formation (294.24-294.21 m b.s.). Heattreated, X-rayed after heating to $500^{\circ} \mathrm{C}$ for 1 hour; Eth.-treated, X-rayed after treatment with ethyleneglycol vapour for 16 hours at $60^{\circ} \mathrm{C}$. Reflection peaks:

CHL, chlorite; ILL, illite; KA, kaolinite;

SM, smectite. The figures represent crystal lattice spacings in Ångstrøms.

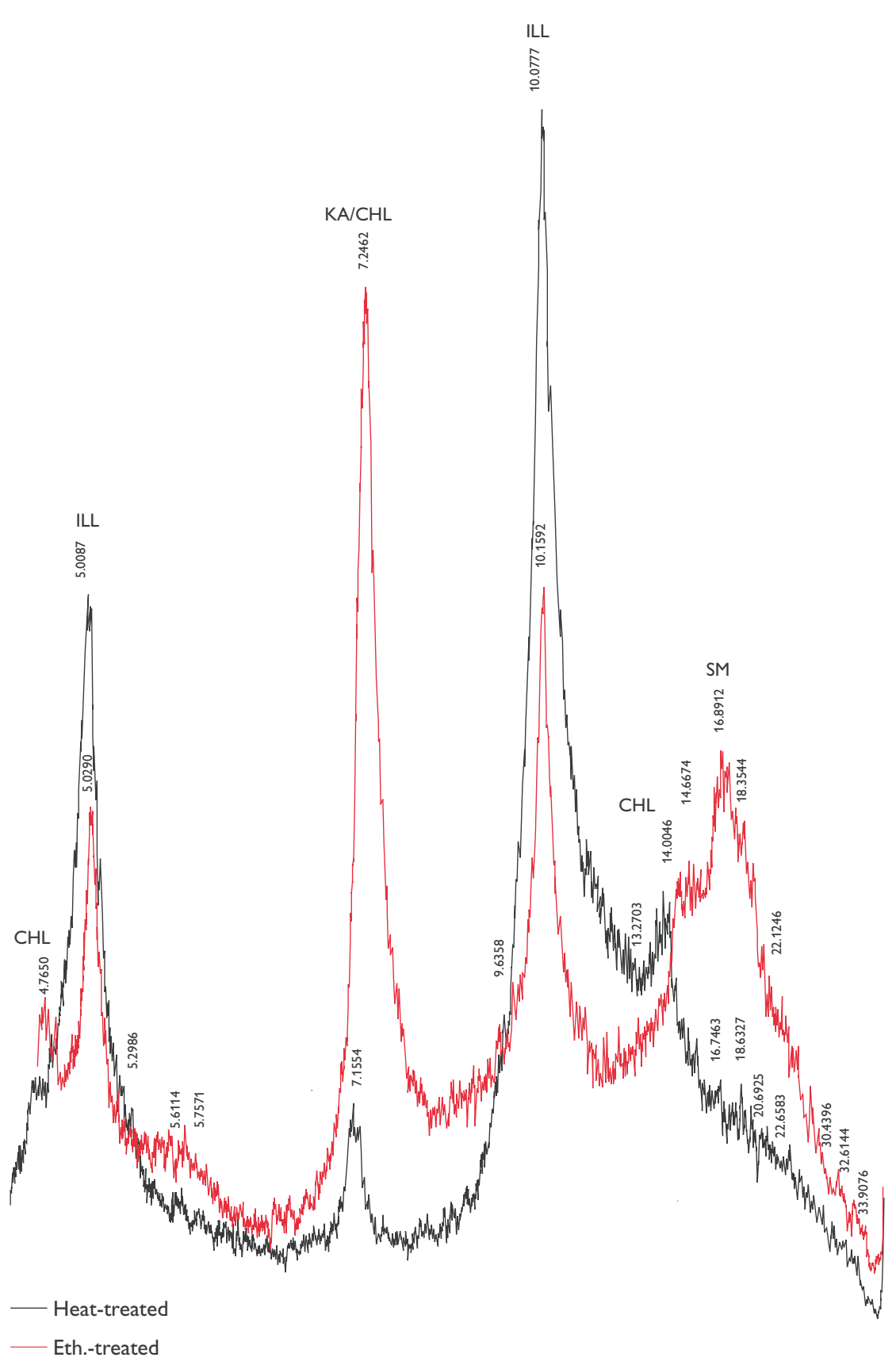

ative to the total clay fraction, corresponding to the overall increase in grain size up-section (Fig. 11). The presence of smectite in the Fjerritslev Formation should be noted as smectite is absent in Jurassic and Lower Cretaceous sediments in most wells in the Danish Basin and the Danish Central Graben (Nielsen 1979, 1985; Clausen 1982; Nielsen \& Friis 1985; Schmidt 1985a; Krabbe 1986; Lindgreen 1991). We believe that the dominance of illite and the presence of illite/smectite mixedlayer minerals in Jurassic sediments in most boreholes, excepting Anholt, is the result of substantial diagenetic illitisation of original smectites due to greater burial depths and thus exposure to higher temperatures.

The transformation of smectites to illites via mixedlayer phases is primarily dependent on burial history, temperature and time (Dunoyer de Segonzac 1970). The transformation is thus seen at different depths and ages in different basins. The process mainly happens within a temperature range of $80-115^{\circ} \mathrm{C}$, normally corresponding to a burial depth of $2-4 \mathrm{~km}$ in the North Sea ('́rodoń \& Eberl 1984). Values of these magnitudes have never been reached for the Anholt sediments. The 
illitisation process starts in sediments with vitrinite reflectance values of approximately $0.5 \% \mathrm{R}_{\mathrm{O}}$, possibly already at $0.40-0.45 \% \mathrm{R}_{\mathrm{o}}$ (Pevear et al. 1980), and Burtner \& Warner (1986) proposed on the basis of Rock-Eval analysis that the process takes place in sediments with $T_{\max }$ values between $430^{\circ}$ and $440^{\circ} \mathrm{C}$, possibly already at $425^{\circ} \mathrm{C}$. In deeply-buried Jurassic successions, such as in the Børglum-1 and Uglev-1 wells, the vitrinite reflectance values for sediments of the Fjerritslev Formation are $0.40-0.50 \% \mathrm{R}_{\mathrm{o}}$ (Schmidt 1985b), i.e. considerably higher than the values from Anholt (0.25-0.40 $\% \mathrm{R}_{\mathrm{o}}$, see below).

The percentage of smectite normally increases with decreasing particle size and towards the basin centre. Because of the marginal location of the Anholt borehole, it is possible that the sediments contain less detrital smectite than contemporaneous sediments in other wells in the Danish Basin prior to diagenetic alteration.

\section{Geochemistry}

The TOC values are shown in Figure 2 and the $\mathrm{S}, \mathrm{Fe}_{2} \mathrm{O}_{3}$ and $\mathrm{K}_{2} \mathrm{O}$ values in Figure 13. Peak values of TOC in the Haldager Sand Formation are related to brown coal layers. Intermediate values of TOC are usually found in brownish/black layers dominated by silt-sized particles, normally with relatively abundant muscovite, or in sand layers with scattered lignite clasts, such as in the middle of the Fjerritslev Formation section. Low TOC values are mainly restricted to layers dominated by clay or coarse-grained quartz sand. The $\mathrm{K}_{2} \mathrm{O}$ content generally reflects the amount of illite, whereas $\mathrm{S}$ and $\mathrm{Fe}_{2} \mathrm{O}_{3}$ reflect the pyrite and to some extent the siderite contents. The percentage of Fe, excluding that incorporated in pyrite or siderite, is relatively uniform.

The analyses were used to calculate a normative mineralogical composition, which was then compared with the XRD mineralogy and used to improve the quantification of the bulk mineralogy from the XRD data. The Anholt borehole is well-suited to such a procedure as: (1) many core-samples have been analysed, (2) the number of different minerals is limited, and (3) the minerals present are rather stable.

\section{Differential thermal analysis (DTA) and step-heated XRD}

The result of the step-wise heating of the sediment for one hour followed by XRD is shown in Figure 14. In sam- ples from the top of the Jurassic section down to a depth of about $230 \mathrm{~m}$, the $7 \AA$ kaolinite peak on X-ray diffractograms is totally destroyed by heating to $500^{\circ} \mathrm{C}$ for one hour; indeed, kaolinite from sand layers in the Haldager Sand Formation is already destroyed at a temperature of $450^{\circ} \mathrm{C}$. From $230 \mathrm{~m}$ down to the base of the borehole at $306 \mathrm{~m}$, the kaolinite structure is only partly destroyed by heating for one hour. The higher the heating temperature and the longer the sample is exposed to this temperature, the greater the destruction. Measurements of different size fractions clearly demonstrated that larger grains were more heat resistant than smaller grains, probably due to a greater proportion of grains with crystal lattice imperfections amongst the smaller size fractions; such size-dependent thermal stability has been noted in many previous studies (e.g. Norton 1939).

With the exception of a single sample at about 250 $\mathrm{m}$, there is a slight tendency for kaolinites in member F-III to be more heat resistant with increasing depth, even if the total amount of kaolinite decreases (Figs 11, 15) and the particle size of the mineral grains decreases (Fig. 8). Figure 15 shows the relationship between core depth and time to destruction of half of the kaolinite particles at $468^{\circ} \mathrm{C}$, i.e. the release of $\mathrm{OH}$-groups corresponding to half of the weight loss observed at this temperature. Generally, the time needed for this destruction increases with increasing depth.

This tendency towards a down-section increase in thermal resistance of kaolinite has been observed elsewhere in Mesozoic sediments of the North Sea Basin. Holdridge \& Vaughan (1957) found the temperature for the onset of dehydroxylation to be $477^{\circ} \mathrm{C}$ for kaolinites (average of 48 samples) and $522.5^{\circ} \mathrm{C}$ for pure dickite (average of 18 samples) through measurement on Differential Temperature Analysis (DTA) equipment at a heating rate of $10^{\circ} \mathrm{C}$ per minute. The lower threshold temperature observed in these Anholt data $\left(468^{\circ} \mathrm{C}\right)$, is probably due to the lower heating rate $\left(2^{\circ} \mathrm{C} / \mathrm{min}\right.$.) used in the present study.

The crystal order presumably increases with the influence of progressive diagenesis. In deeper diagenesis/incipient metamorphism, kaolinites may convert to dickite and further to nacrite with the same chemical composition as kaolinite, but with a higher degree of order in the crystal lattice (Dunoyer de Segonzac 1970). The results of the analysis of the thermal stability of kaolinites from the Anholt borehole indicate that the thermal stabilisation of kaolinites during progressive diagenesis is a gradual process. The process seems to initiate at a relatively early diagenetic stage; thermal stabilisation is detectable at diagenetic stages reached 
Fig. 13. The content (\%) of $\mathrm{K}_{2} \mathrm{O}, \mathrm{Fe}_{2} \mathrm{O}_{3}$, and $\mathrm{S}$ determined from the bulk geochemical analysis. Quat., Quaternary; m b.s., metres below surface.
Fig. 14. Peak ratios (peak height of heated samples/peak height of ethyleneglycol-treated samples) for $7 \AA$ kaolinite heated to $500^{\circ} \mathrm{C}, 525^{\circ} \mathrm{C}$ and $550^{\circ} \mathrm{C}$.

m b.s., metres below surface.
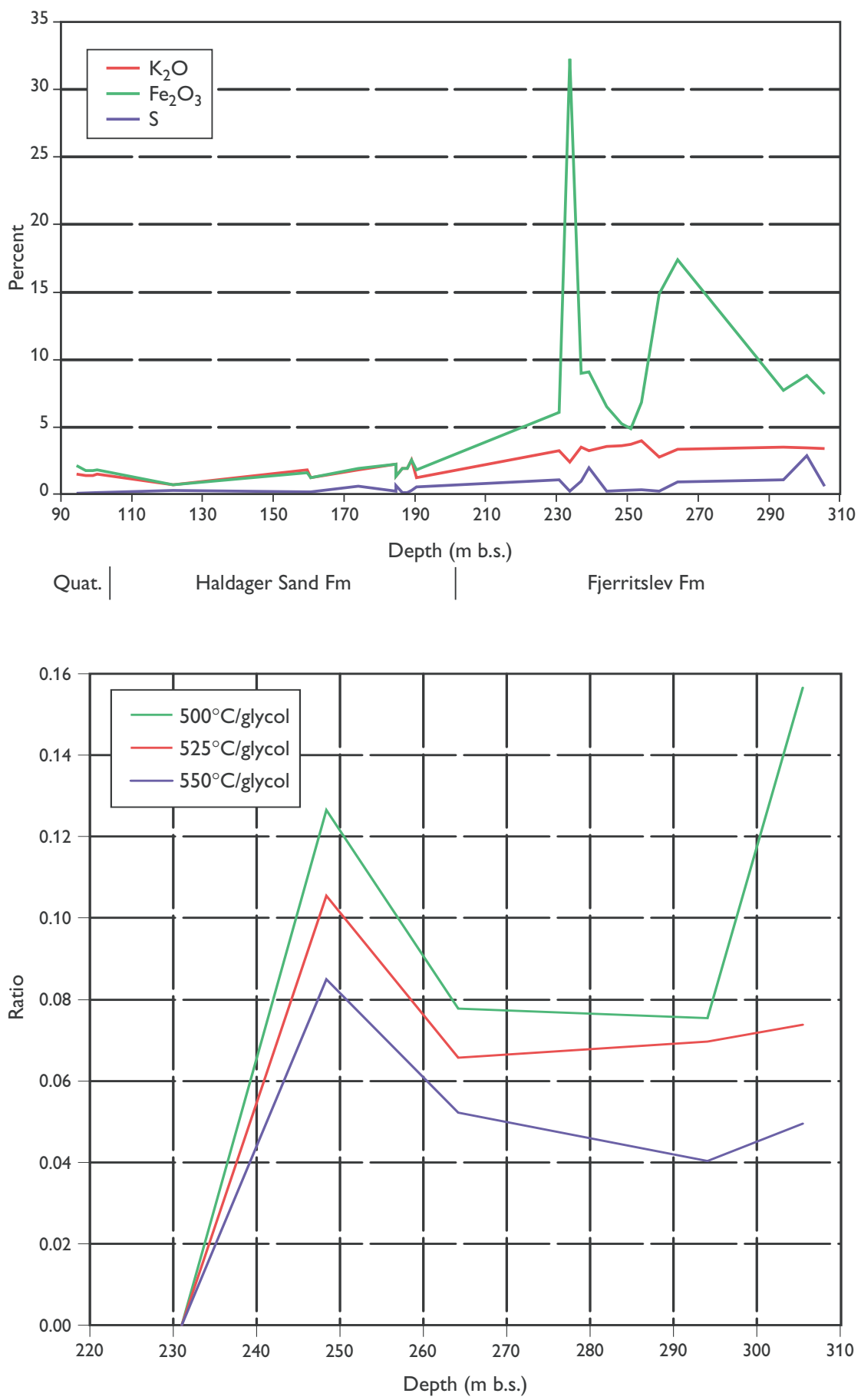

at a depth of approximately $1 \mathrm{~km}$. It also seems possible to differentiate the thermal stability of kaolinites within a depth range of 100-200 m. Kaolinite in sands of the Haldager Sand Formation is commonly seen as a whitish powder on the quartz grains. The very low thermal resistance of this kaolinite might be explained by a later, probably post-uplift, formation in the pore spaces of the sand. The formation of kaolinite is possibly due to reactions between a migrating diluted acidic porewater and feldspar grains (Nielsen \& Friis 1985).

\section{Organic petrology and geochemistry}

A total of 46 samples from the Anholt borehole were selected for TOC and Rock-Eval screening. The samples were selected mainly from the darker grey, brownish or black sediment levels where higher organic contents were expected. From the screening results, 23 samples were selected for organic petrographical analyses, i.e. measurements of vitrinite reflectance and fluorescence, and compositional description. 


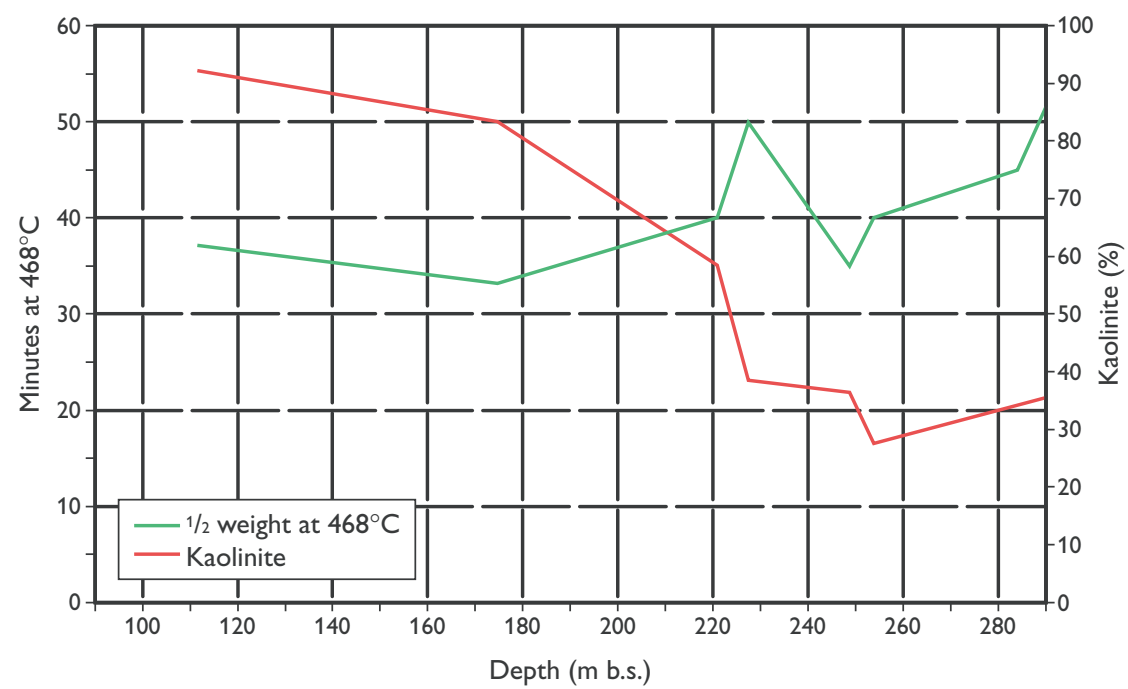

Fig. 15. The proportion of kaolinite (\%) relative to the total clay mineral content of the clay fraction $(<2 \mu \mathrm{m})$ and the time taken in minutes for the release of half of the OH-groups in kaolinite at $468^{\circ} \mathrm{C}$, measured by differential thermal gravimetry. m b.s., metres below surface.

\section{TOC and Rock-Eval screening}

Most of the samples are very poor in total organic carbon (TOC). The hydrocarbon potential (HC) is also low (S2 values are low; Table 1). S2 values (S2: hydrocarbons generated during Rock-Eval pyrolysis) of $<0.5$ mg hydrocarbon (HC)/g rock are considered to give unreliable $T_{\max }$ values ( $T_{\max }$ : Temperature of maximum hydrocarbon generation during Rock-Eval pyrolysis). The highest TOC values are from the upper sandy section of the Haldager Sand Formation from a depth of about 190-105 m, whereas the values from the underlying greenish clays of the Fjerritslev Formation are low to very low. The varying content of organic/coaly debris in the sediments is confirmed by the wide range of variation in TOC values. The highest value (38\%) was obtained from a thin lignite layer.

The $T_{\max }$ varies in the range $410-433^{\circ} \mathrm{C}$, with most of the values around $420-425^{\circ} \mathrm{C}$ (Table 1 ). The lowest value of $387^{\circ} \mathrm{C}$ from the brown coal bed is considered to be unreliable. The highest value of $433^{\circ} \mathrm{C}$ is most likely due to the presence of slightly oxidised or reworked material and not due to maturation.

The dominant $T_{\max }$ values of about $420-425^{\circ} \mathrm{C}$ are within the expected range for sediments with the measured vitrinite reflectance values (see below) of about $0.4 \% \mathrm{R}_{\mathrm{o}}$ (Tissot et al. 1987). The HI (hydrogen index) below or just above $100 \mathrm{mg} \mathrm{HC} / \mathrm{gTOC}$ (Table 1) is typical of kerogen types III-IV. Only one sample yielded a higher HI value (276 mg HC/g TOC).

\section{Coal petrography}

The samples selected for coal petrographic description were embedded in cold synthetic resin, and were ground and polished after hardening. All samples were studied in normal reflected light combined with blue lightinduced fluorescence. The organic material was described and the maceral composition was estimated semi-quantitatively in the following groups: vitrinite, pseudovitrinite, inertinite and liptinite. The main focus was on the degree of oxidation and the liptinite composition. Point counting was not performed; the results of the coal petrographic analysis are given in Table 2 .

The organic material in all samples is, in general, dominated by terrestrial material. Most samples are characterised by humic material (vitrinite) showing varying degrees of oxidation and/or reworking (pseudovitrinite and inertinite). Samples 3 and 8, from $121.6 \mathrm{~m}$ and $170.9 \mathrm{~m}$ respectively, are composed entirely of large fragments of ulminitic vitrinite with almost no indication of oxidation. In contrast, sample 10 (184.48 m) contains humic material composed almost entirely of oxidised inertinite, mainly tiny small fusinite fragments, or pseudovitrinite.

In general, the liptinitic content is low, but the identifiable part shows a high abundance of macerals of terrestrial origin, such as sporinite, resinite and cutinite, sometimes even with possible fluorinite. Only very few algae were identified. In the upper part of the section, a few of the Botryococcus-type occur, indicating deposition in (or derivation from) fresh to brackish water, and a Tasmanites was observed in sample $10(184.48 \mathrm{~m})$. Marine organic material, such as tiny fragments of dinocysts or acritarchs, is present only in the lowermost 
Table 1. Rock-Eval screening results and vitrinite reflectance

\begin{tabular}{|c|c|c|c|c|c|c|c|c|c|c|}
\hline Sample & $\begin{array}{l}\text { Depth } \\
(\mathrm{m})\end{array}$ & $\begin{array}{c}\text { TOC } \\
\text { (wt\%) }\end{array}$ & $\begin{array}{l}T_{\max } \\
\left({ }^{\circ} \mathrm{C}\right)\end{array}$ & $\begin{array}{c}\mathrm{S} 1 \\
\text { (mg } \\
\mathrm{HC} / \mathrm{g} \\
\text { rock) }\end{array}$ & $\begin{array}{c}\mathrm{S} 2 \\
(\mathrm{mg} \\
\mathrm{HC} / \mathrm{g} \\
\text { rock) }\end{array}$ & $\mathrm{PI}$ & $\begin{array}{c}\text { PC } \\
\text { (wt\%) }\end{array}$ & $\mathrm{HI}$ & $\% R_{\circ}$ & $\mathrm{n}$ \\
\hline 1 & 113.6 & & & & & & & & 0.30 & 52 \\
\hline 2 & 119.82-119.85 & 11.00 & 417 & 1.08 & 12.17 & 0.08 & 1.10 & 111 & 0.33 & 51 \\
\hline 3 & $121.59-121.60$ & 38.00 & 387 & 5.70 & 31.07 & 0.16 & 3.05 & 82 & 0.32 & 63 \\
\hline \multirow[t]{2}{*}{4} & $124.6-127.6$ & 3.74 & 427 & 0.19 & 3.15 & 0.06 & 0.28 & 84 & 0.33 & 39 \\
\hline & $130.6-133.6$ & 2.02 & 426 & 0.11 & 1.25 & 0.08 & 0.11 & 62 & & \\
\hline \multirow[t]{5}{*}{5} & $133.6-136.6$ & 2.11 & 423 & 0.07 & 0.97 & 0.07 & 0.09 & 46 & 0.37 & 49 \\
\hline & $137.4-139.6$ & 0.17 & 424 & 0.01 & 0.01 & 0.50 & 0.00 & 6 & & \\
\hline & $142.6-145.6$ & 0.17 & 404 & 0.03 & 0.05 & 0.38 & 0.01 & 30 & & \\
\hline & $145.6-147.1$ & 1.35 & 425 & 0.01 & 0.11 & 0.08 & 0.01 & 8 & & \\
\hline & $147.1-148.6$ & 2.43 & 424 & 0.05 & 0.91 & 0.05 & 0.08 & 37 & & \\
\hline \multirow[t]{2}{*}{6} & 149.90 & 0.70 & 426 & 0.12 & 1.94 & 0.06 & 0.17 & 276 & 0.35 & 50 \\
\hline & $154.6-157.6$ & 2.44 & 423 & 0.03 & 0.23 & 0.12 & 0.02 & 9 & & \\
\hline 7 & 159.59-159.74 & 2.40 & 424 & 0.13 & 1.74 & 0.07 & 0.16 & 73 & 0.35 & 52 \\
\hline 8 & $170.8-170.90$ & 5.89 & 410 & 0.35 & 2.67 & 0.12 & 0.25 & 45 & 0.32 & 55 \\
\hline \multirow[t]{2}{*}{9} & 175.55 & 1.81 & 423 & 0.03 & 0.79 & 0.04 & 0.07 & 44 & 0.43 & 43 \\
\hline & 184.09-184.10 & 0.77 & 427 & 0.01 & 0.24 & 0.04 & 0.02 & 31 & & \\
\hline \multirow[t]{2}{*}{10} & 184.80 & 9.50 & 427 & 0.46 & 5.94 & 0.07 & 0.53 & 63 & 0.34 & 7 \\
\hline & 184.98 & 1.73 & 421 & 0.07 & 1.32 & 0.05 & 0.12 & 76 & & \\
\hline 11 & 187.82 & 1.50 & 418 & 0.03 & 0.59 & 0.05 & 0.05 & 39 & 0.34 & 30 \\
\hline \multirow[t]{2}{*}{12} & 189.65 & 0.49 & 431 & 0.00 & 0.07 & & & 14 & 0.32 & 27 \\
\hline & 194.6-197.6 & 0.12 & & 0.01 & 0.00 & & & & & \\
\hline \multirow[t]{3}{*}{13} & $206.6-209.6$ & 0.63 & 424 & 0.03 & 0.36 & 0.08 & 0.03 & 57 & 0.34 & 30 \\
\hline & $209.6-210.3$ & 0.38 & 425 & 0.03 & 0.15 & 0.17 & 0.01 & 40 & & \\
\hline & $212.6-215.6$ & 0.31 & 422 & 0.03 & 0.13 & 0.19 & 0.01 & 42 & & \\
\hline \multirow[t]{2}{*}{14} & $218.6-221.6$ & 0.31 & 425 & 0.05 & 0.13 & 0.28 & 0.01 & 42 & 0.32 & 50 \\
\hline & $221.6-224.6$ & 0.28 & 422 & 0.05 & 0.11 & 0.31 & 0.01 & 40 & & \\
\hline \multirow[t]{2}{*}{15} & 230.53 & 1.19 & 422 & 0.03 & 0.50 & 0.05 & 0.05 & 50 & 0.33 & 51 \\
\hline & 234.36 & 0.16 & 431 & 0.00 & 0.07 & & & 44 & & \\
\hline \multirow[t]{2}{*}{16} & 239.28 & 0.72 & 429 & 0.01 & 0.42 & 0.02 & 0.04 & 58 & 0.31 & 14 \\
\hline & 244.15 & 1.20 & 427 & 0.01 & 1.31 & 0.01 & 0.11 & 109 & & \\
\hline \multirow[t]{4}{*}{17} & 249.68 & 0.24 & 429 & 0.00 & 0.17 & & & 69 & 0.29 & 8 \\
\hline & 255.16 & 0.22 & 432 & 0.00 & 0.07 & & & 32 & & \\
\hline & 260.59 & 0.21 & 434 & 0.00 & 0.13 & & & 61 & & \\
\hline & 264.20 & 0.28 & 420 & 0.00 & 0.17 & & & 60 & & \\
\hline \multirow[t]{2}{*}{18} & 270.70 & 0.50 & 420 & 0.01 & 0.25 & 0.04 & 0.02 & 50 & & \\
\hline & 274.80 & 0.19 & 419 & 0.00 & 0.07 & & & 38 & & \\
\hline \multirow[t]{2}{*}{19} & 280.09 & 0.17 & 414 & 0.01 & 0.07 & 0.13 & 0.01 & 41 & & \\
\hline & 285.70 & 0.20 & 416 & 0.00 & 0.07 & & & 36 & & \\
\hline 20 & 290.08 & 0.45 & 420 & 0.01 & 0.30 & 0.03 & 0.03 & 67 & 0.31 & 8 \\
\hline 21 & 295.08 & 0.42 & 416 & 0.01 & 0.25 & 0.04 & 0.02 & 59 & & \\
\hline 22 & 300.08 & 1.08 & 420 & 0.05 & 1.01 & 0.05 & 0.09 & 94 & 0.34 & 38 \\
\hline 23 & 304.08 & 0.66 & 423 & 0.01 & 0.34 & 0.03 & 0.03 & 52 & 0.35 & 36 \\
\hline
\end{tabular}

TOC: Total organic carbon.

$T_{\max }$ : Temperature of maximum hydrocarbon generation during pyrolysis.

PC: Pyrolysable carbon $[0.083(\mathrm{~S} 1+\mathrm{S} 2)]$.

S1: Thermally-extracted hydrocarbons.

S2: Hydrocarbons generated during Rock-Eval pyrolysis.

PI: $\quad$ Production index [S1/(S1+S2)], derived from Rock-Eval pyrolysis.

$\mathrm{HI}$ Hydrogen index $[100 \times \mathrm{S} 2 / \mathrm{TOC}]$.

$\% R_{o}$ : Vitrinite reflectance.

$\mathrm{n}$ : Number of measurements. part of the succession. A very small amount of bituminite was also recognised in these samples. Sample 22 $(300.88 \mathrm{~m})$ has the highest proportion of what may be considered to be marine material. The organic material in the uppermost part of the Fjerritslev Formation is of very poor quality compared to data from other wells in the Danish area (Thomsen et al. 1987).

\section{Vitrinite reflectance and fluorescence data}

Reflectance measurements were performed on the same polished specimens as used for description of the organic composition. The photomultiplier attached to the 'Zeiss Photomicroscope' was calibrated by measurements on a polished optical glass standard of constant known 
Table 2. Composition of the organic material

\begin{tabular}{|c|c|c|c|c|c|c|c|c|c|c|c|c|c|c|c|}
\hline \multirow[t]{2}{*}{ Sample } & \multirow{2}{*}{$\begin{array}{l}\text { Maximum } \\
\text { depth } \\
\text { (m) }\end{array}$} & \multirow{2}{*}{$\begin{array}{l}\text { Organic } \\
\text { content }\end{array}$} & \multicolumn{4}{|c|}{ Maceral composition } & \multirow[b]{2}{*}{ 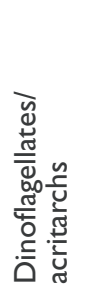 } & \multirow[b]{2}{*}{ 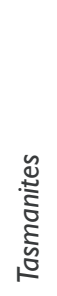 } & \multicolumn{5}{|c|}{ Liptinite composition } & \multirow[b]{2}{*}{ 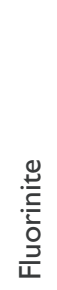 } & \multirow[b]{2}{*}{ 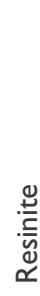 } \\
\hline & & & 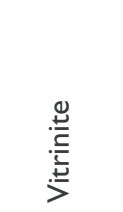 & 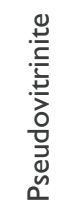 & 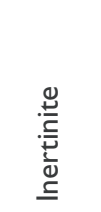 & . & & & 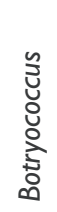 & 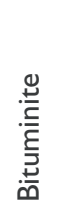 & 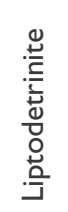 & 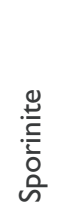 & : & & \\
\hline 1 & 113.6 & Moderate & $X X X X$ & $x$ & $x$ & - & & & & & $x$ & $x$ & $x$ & & $x$ \\
\hline 2 & 119.85 & High & $X X X$ & $X X$ & $x$ & $x$ & & & & & $x$ & $x X$ & $x$ & & $x$ \\
\hline 3 & 121.60 & Very high & $X X X X X$ & & & - & & & & & & & & & - \\
\hline 4 & 127.60 & Moderate & $x x$ & $X X$ & $x x$ & $x$ & & & - & & $x$ & $x X$ & & & $x$ \\
\hline 5 & 136.60 & Moderate & $x$ & $x X x$ & $x x$ & - & & & & & $x$ & $x$ & & & \\
\hline 6 & 149.90 & Moderate & $X X X$ & $X X$ & $x$ & $x$ & & & - & & $x$ & $x X$ & $X X$ & & \\
\hline 7 & 159.70 & Moderate & $X X X$ & $X X$ & $x$ & $x$ & & & - & & $x$ & $x$ & $X X$ & & \\
\hline 8 & 170.90 & High & $X X X X X$ & & $x$ & - & & & & & - & & - & & \\
\hline 9 & 175.55 & Moderate & $X X X$ & $X X$ & $x$ & - & & & & & $x$ & $x$ & $x$ & & \\
\hline 10 & 184.48 & High & $x$ & $X X$ & $X X X X$ & $x$ & & & - & & $x x$ & $x$ & $x$ & & \\
\hline 11 & 187.82 & Moderate & $X X X X$ & $x$ & $x$ & $x$ & & - & & & $x$ & $x$ & $X X$ & $x$ & \\
\hline 12 & 189.65 & Low & $X X X$ & $x$ & $x$ & - & & & & & - & & & & \\
\hline 13 & 209.60 & Low & $X X X$ & $x x$ & $x$ & - & & & & & & $x$ & $X X$ & $x$ & $x$ \\
\hline 14 & 221.60 & Low & $X X X X$ & $x$ & $x$ & - & & & & & - & & $x$ & $x$ & \\
\hline 15 & 230.53 & Low & $x x$ & $X X$ & $x x$ & $x$ & & & & & $x$ & $x$ & & & \\
\hline 16 & 239.28 & Low & $x X X X$ & $x$ & & $x x$ & & & & & $x$ & & $X X$ & & - \\
\hline 17 & 249.68 & Low & $X X X$ & $x$ & $x$ & - & & & & & - & & & & \\
\hline 18 & 270.70 & Very low & $X X X X$ & $x$ & $x$ & - & & & & & - & & & & \\
\hline 19 & 280.09 & Very low & $X X X$ & $x$ & $x$ & - & & & & & - & & & & \\
\hline 20 & 290.08 & Low & $x$ & $x x$ & $x x$ & $x$ & - & & & & $x$ & $x$ & & & \\
\hline 21 & 295.08 & Low & $x$ & $X X$ & $x x$ & $x x$ & - & & & $x$ & $X X$ & $x$ & & & \\
\hline 22 & 300.88 & Low & $x x$ & $x$ & $x$ & $X X X$ & $x$ & & - & $x x$ & $x$ & & & & \\
\hline 23 & 304.08 & Low & $X X X$ & $X X$ & $x$ & $x$ & & & - & $x$ & $x$ & & & & \\
\hline
\end{tabular}

$X$ : Abundance, ranked in terms of relative abundance $(X-X X X X X)$.

-: Observed.

reflectance. The reflectance measurements are reported as the percentage $\left(\% \mathrm{R}_{\mathrm{o}}\right)$ of the incident light reflected from the plane surface of the vitrinite surface when immersed in oil.

The abundance of vitrinite particles is good for reflectance measurements, even in the lean samples, as most samples are dominated by humic material. In general, as many measurements as allowed by the available material were performed, and the quality of the data was noted. The average values shown in Table 1 are based on reflectance measurements that were considered to be reliable. The most reliable data are considered to be from the coaly samples where the particles are so large that a detailed maceral identification is possible, and therefore the results are more reliable com- pared with samples containing fine-grained dispersed organic matter.

In sample $3(121.6 \mathrm{~m})$, the organic material is represented entirely by large particles of woody tissue and the measurements were performed on texto-ulminite. The range of values is very narrow $\left(0.25-0.40 \% \mathrm{R}_{\mathrm{o}}\right)$ with an average of $0.32 \% \mathrm{R}_{\mathrm{o}}$ from a total of 62 measurements. Reflectance values from corpohuminite, which is also common, have the same range and almost the same average $\left(0.31 \% \mathrm{R}_{\mathrm{o}}\right)$.

The range of values in the other samples is somewhat larger, though still between 0.2 and $0.5 \% \mathrm{R}_{\mathrm{o}}$. The best data quality is generally obtained from the upper coaly samples, whereas the quality decreases in some of the lowermost samples where the particle size of the 
vitrinite is smaller and the morphological affinity of the vitrinite less obvious. The poorer quality is indicated by the wider range of the reflectance data. In samples 18, 19 and 21, it was not possible to perform measurements but the range of reflectance data in Table 1 is considered reliable, due to the relatively large number of measurements on each sample.

Spectral fluorescence measurements were performed on a Leitz Orthoplan microscope equipped with a Hamamatsu photomultiplier and a Ploemopak for measurements and observations. The spectra were measured and their $\mathrm{Q}$ value recorded $(\mathrm{Q}=$ relative fluorescence intensity at $650 \mathrm{~nm} /$ relative fluorescence intensity at $500 \mathrm{~nm}$ ). It was only possible to make fluorescence measurements on a few samples containing alginite, i.e. samples 4, 6, 7, 10, 21 and 22. The mainly yellowish-green fluorescence colours of the algal bodies indicate their degree of immaturity and correspond to their vitrinite reflectance values. All average Q values are between 0.4 and 0.5 , corresponding to the measured vitrinite reflectance values (Schmidt 1989).

\section{Uplift}

The increase in vitrinite reflectance down-section is the result of chemical processes controlled by time and temperature; the increase is linear with respect to time and exponential with respect to temperature (Waples 1985). The changes to the chemical structure of the vitrinite are irreversible, and therefore the vitrinite reflectance reflects the maximum temperature to which the sediment has been exposed during burial. Uplift will consequently not cause any change in the vitrinite reflectance. A difference between measured reflectance values from a certain depth and estimated reflectance values for that depth can therefore be used as an indication of the magnitude of uplift.

A reflectance value of $0.20 \% \mathrm{R}_{\mathrm{o}}$ is normal for zero coalification at the depositional surface (Teichmüller \& Teichmüller 1979). Reflectance values above $0.3 \% \mathrm{R}_{\mathrm{o}}$ may first be expected at a depth of at least $1000 \mathrm{~m}$ in areas of the North Sea with no uplift but a similar temperature history (Hansen \& Thomsen 1990; Schmidt 1990). The range of reflectance values slightly above $0.3 \% \mathrm{R}_{\mathrm{o}}$ suggests that some uplift and erosion has taken place. The uplift is estimated to have been about $1000 \mathrm{~m}$; a comparable value $(975 \mathrm{~m})$ was obtained by Petersen et al. (2003, this volume) who utilised the reflectance data reported here but applied a coalification curve derived from the Danish Basin.
Study of the organic material has thus indicated that:

1. The degree of diagenetic maturation is relatively low, but higher than expected for sediments at a depth range of approximately $100-300 \mathrm{~m}$.

2. The ranges of $T_{\max }$, vitrinite reflectance and $\mathrm{Q}$ values suggest that the deposits have been exposed to temperatures that are commonly present at c. 1000 m depth.

3. The HI values and the coal petrographic interpretation indicate a terrestrial origin for most of the organic material.

4. The content of marine organic material is very low, and restricted to the lowermost few metres of the cored section.

\section{Discussion}

\section{Palaeoenvironment}

Nodosarid foraminifera, such as those found in the lowermost part of the borehole in foraminiferal zone FA from 306-304 m, referred to member F-III of the Fjerritslev Formation, were typical of normal marine shelf conditions during the Jurassic period (e.g. Nagy et al. 1990). The nodosarid assemblage combined with the abundant dinoflagellate cysts of low diversity, the occurrence of ammonites, fish remains, bioturbation, the alternating clay and fine-grained sand lithology, and the low TOC content (below 1\%; Fig. 2) suggest that a marine, inner shelf environment with well-oxygenated bottom conditions prevailed during the late Pliensbachian (Seidenkrantz et al. 1993; Nagy \& Seidenkrantz in press). Storm sands are common and relatively coarse-grained in the lowermost levels of the borehole (306-300 m). In contrast to this basal interval, the storm sands become less abundant and finer-grained above $300 \mathrm{~m}$, although their abundance and grain-size varies, with a slight tendency to become more abundant and coarser upwards between $300 \mathrm{~m}$ and $260 \mathrm{~m}$.

In the uppermost Pliensbachian - Toarcian, bioturbation is less prominent and the clay-rich sediment contains an upwards increasing proportion of storm sand laminae, especially from $260 \mathrm{~m}$. The thickness and grain size of the sand laminae also increase upwards, suggesting a gradual decrease in water depth through the Toarcian. This is supported by the low abundance of 
marine dinoflagellates, decreasing up-section, and the low-diversity agglutinated foraminiferal fauna (Seidenkrantz et al. 1993; Nagy \& Seidenkrantz in press). Such foraminiferal assemblages may reflect low salinity, oxygen deficiency, turbulent conditions or rapid sedimentation and were characteristic of deltaic or prodeltaic environments in the Jurassic (Løfaldli \& Nagy 1980; Nagy et al. 1988, 1990, 1995). Thus, the dominance of Ammobaculites, Bulbobaculites, Kutsevella and Haplophragmoides, as well as the low diversity (cf. Nagy et al. 1984, 1990; Nagy 1992) suggest that the uppermost Pliensbachian - Toarcian sediments at Anholt record progressive shallowing of the environment. The presence of a few ammonite fragments and some dinoflagellate cysts show that marine influence persisted. The absence of ostracods, the scarcity of burrows and the relatively common occurrence of Haplophragmoides may reflect reduced oxygen conditions at the sea floor.

During the following main part of the Toarcian succession (upper palynomorph zone PB, 288-231 m) the sparse agglutinated foraminifera (Ammobaculites and Bulbobaculites) and the marine dinoflagellate cysts gradually disappear. Upwards, storm-generated sand layers become more frequent, thicker and coarser and, especially above $260 \mathrm{~m}$, these sands have erosional bases and show cross-lamination. This supports the interpretation of a progressive shallowing, indicated by the palaeobiological data. In the upper part of the interval, the presence of scattered lignite clasts and the increased proportion of reworked palynomorphs suggest an increasing supply of particles from a shallower part of the coastal zone, temporarily exposed to erosion, and/or from a neighbouring coastal plain. The coal petrographic interpretation indicates that most of the organic material has a terrestrial origin.

Member F-IV of the Fjerritslev Formation (231-201 m) is broadly referred to the Aalenian Stage. There are only few cores in this section, but the presence of layers with relatively low total gamma-ray signals, indicates that substantial parts of the unit consist of sand and silty sand and were deposited under higher energy conditions than the sediments below. The palynomorph assemblage contains a significant proportion of freshwater algae (palynomorph zone PC), which, combined with the occurrence of brackish-marine dinoflagellates and acritarchs, indicates a brackish-marine influence in the deltaic environment.

The remaining part of the Jurassic section, the uppermost Aalenian - Bajocian/Bathonian Haldager Sand Formation (201-104 m), represents a delta plain environment with only occasional brackish water influence in the lower part. This is shown by the absence of foraminifera and dinoflagellates, by the occurrence of acritarchs only in the lower part, and by the presence of brackish to freshwater algae throughout the section. The coal petrographic analysis indicates a marked dominance of terrestrial material, commonly with a varying degree of oxidation of the organic material. The cyclic alteration of sand, pebbly sand, clay, and lignite supports the delta plain interpretation. In the lowermost Haldager Sand Formation, however, discrete thin finegrained sand beds are significantly enriched in Th and U (Fig. 7), probably reflecting concentration of heavy minerals under high-energy (beach?) conditions.

\section{Comparison with the central Danish Basin}

Our data indicate that at Anholt most of the Toarcian period was characterised by decreasing water depths. In the lower part of the Toarcian section, evidence of shallowing is less pronounced, but is very distinct in the mid-Toarcian section. In the central Danish Basin, much of the Toarcian was characterised by an increase in water depth (Michelsen 1978, 1989a), which may be correlated with a global sea-level rise (Hallam 1988). The sea-level rise led to the establishment of stagnant bottom conditions (Pedersen 1986; Michelsen 1989a). In the central part of the Danish Basin, the shallowing of the basin first began in the Late Toarcian (Michelsen 1989a, b).

Although the biostratigraphic data from Anholt does not prove the presence of a complete Toarcian section, we believe that most of the Toarcian Stage is represented, at least within the section of complete recovery below $248 \mathrm{~m}$, as no indications of hiatuses have been observed here. It is deemed likely, therefore, that the regressive, shallowing event was initiated earlier at Anholt than in the central parts of the Danish Basin.

We suggest that such an early regressive tendency at Anholt may be explained by the palaeogeographical position of the site. Anholt is located in a marginal position relative to the Danish Basin and it is possible that progradation of the delta plain that characterised the entire Danish Basin in the Middle Jurassic (Michelsen 1978), may have influenced Anholt earlier than elsewhere in the basin. Another possible explanation may be sought in local tectonic uplift in the Fennoscandian Border Zone, but we have no other indications of such an Early Jurassic uplift in the area.

The boundary between the Fjerritslev and Haldager Sand Formations in the Danish Basin has previously been considered to coincide with the Lower-Middle Jurassic 
boundary (Michelsen 1978, 1989b) although Michelsen \& Nielsen (1991) suggested that the uppermost part of the Fjerritslev Formation may be Aalenian in age. Our analyses have shown that member F-IV of the Fjerritslev Formation was deposited in Aalenian time. At Anholt, the Toarcian-Aalenian boundary (i.e. the Lower-Middle Jurassic boundary) is thought to correspond broadly to the boundary between members F-III and F-IV of the Fjerritslev Formation (Fig. 3).

\section{Post-depositional history and diagenesis}

The depth interval with vitrinite reflectance data is only about $200 \mathrm{~m}$ thick and a depth-related trend in reflectance is not evident. Nevertheless, a tentative estimate of uplift has been derived, suggesting that about $1000 \mathrm{~m}$ of overburden are missing; this figure is compatible with that derived by Petersen et al. (2003, this volume). This indicates that the maximum post-depo- sitional subsidence of the Jurassic sediments at Anholt was about $1100-1300 \mathrm{~m}$. This value is not very accurate, but the range seems to fit well with data obtained from other methods for quantification of uplift and erosion such as shale compaction, where sonic and density logs are used to estimate the magnitude of uplift (Strømnes 1991; Japsen 1992; Jensen \& Michelsen 1992; Jensen \& Schmidt 1992, 1993; Lykke-Andersen et al. 1993). The range of uplift values is compatible with values estimated from the northernmost part of Jylland (Japsen 1992; Jensen \& Michelsen 1992; Jensen \& Schmidt 1992, 1993). Together they define a regional uplift trend almost parallel to the Fennoscandian Border Zone.

The regional trend in uplift for the Danish area shows that no uplift or erosion has occurred in the Central Graben, whereas increasing uplift took place in a northeasterly direction towards the Norwegian-Swedish coast, reaching a maximum of about $1500 \mathrm{~m}$. Figure 16 shows how the data from Anholt fit into this overall trend. Though the magnitude of uplift estimated from differ-

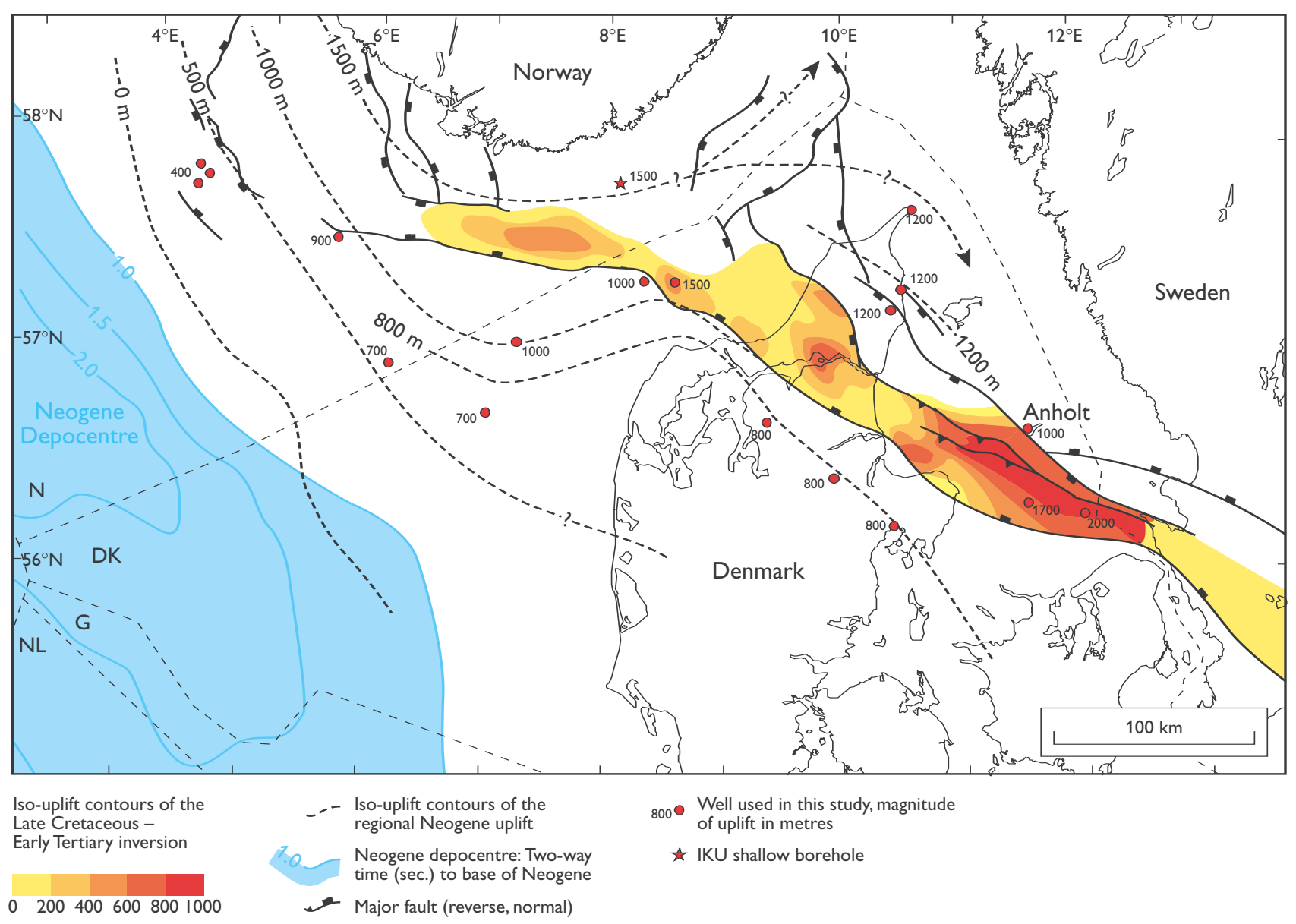

Fig. 16. Iso-uplift map of the Danish Basin. Modified from Jensen \& Michelsen (1992). North Sea sectors: DK, Denmark; G, Germany; $\mathbf{N}$, Norway; NL, the Netherlands. 
ent methods differs somewhat (Japsen 1992, 1993), the overall trend in regional uplift superimposed by inversion along the Sorgenfrei-Tornquist Zone is clear.

Anholt is situated close to the Sorgenfrei-Tornquist Zone which was inverted during Late Cretaceous Early Tertiary times. This zone is characterised by very high total uplift values reaching about $2000 \mathrm{~m}$ (e.g. for the Terne-1 well; B.J. Schmidt and L.N. Jensen, personal communications 1994) representing an addition of 600-700 $\mathrm{m}$ to the regional uplift. However, the uplift at Anholt does not reach a magnitude which demands a contribution from Late Cretaceous - Early Paleocene uplift within the inversion zone (Fig. 16). A structural map of the Top Chalk Group (Ter-Borch 1987) shows that Upper Cretaceous sediments are found at depths of 150-250 m below sea level both to the NE and SW of Anholt. On Anholt, Lower-Middle Jurassic sediments occur at this depth, indicating differential uplift of the Anholt site of at least this magnitude relative to the areas to the NE and SW. This uplift might have taken place during the inversion of the Sorgenfrei-Tornquist Zone. Thus, part of the uplift probably took place during the Late Cretaceous - Paleocene inversion, but the main uplift of the area took place in Oligocene-Recent times as part of the regional uplift of Scandinavia.

The mineralogical composition, dominated by detrital quartz, muscovite/illite and kaolinite, with a subordinate smectite contribution increasing down-section, indicates that the source areas for the Jurassic sediments had been exposed to intense weathering. Diagenetic minerals such as chlorite are present in the lower part, but the presence of smectite demonstrates that the illitisation process, seen in most other wells in the Danish Basin, has not been significant. This is in accordance with the relatively minor post-Jurassic subsidence of the Anholt area. The thermal stability of the kaolinite increases down-section. The well-crystallised authigenic kaolinite in the sand layers of the Haldager Sand Formation is less thermally stable than the detrital kaolinite. This indicates that the authigenic kaolinite formed after or during the Late Cretaceous - Tertiary uplift and thus was not thermally stabilised during the subsidence-related progressive diagenesis.

The Spectral Natural Gamma-ray log has enabled better definition of the lithological boundaries, especially in sections with poor core recovery. In the transition between the marine clays and the non-marine sands, very high concentrations of Th and $\mathrm{U}$ are present in relatively thin and well-defined layers. The origin of these layers is not yet fully known, but concentration of Th- and U-rich heavy minerals in a beach setting is thought to have been the dominant process.

\section{Conclusions}

The present study has shown that member F-III of the Fjerritslev Formation in the Anholt borehole is of Pliensbachian-Toarcian age, member F-IV is of Aalenian age and the Haldager Sand Formation is of latest Aalenian - Bajocian/Bathonian age.

The sediments of the Fjerritslev Formation are mostly marine clays with varying proportions of storm sand laminae that generally increase up-section in abundance, thickness and grain-size. The Haldager Sand Formation consists of an alteration of non-marine sand, clay and a few lignite layers. The sand layers are dominated by quartz and muscovite and, in the Haldager Sand Formation, authigenic kaolinite and lignite clasts. The clays are dominated by kaolinite and illite with subordinate smectite, increasing in proportion down-section, and muscovite. In the lowermost Haldager Sand Formation, the presence of heavy mineral-enriched fine-grained sand layers is inferred from geochemical anomalies.

Siderite and pyrite are commonly present as concretions, whereas calcite is only found in one concretion. The sand layers are unconsolidated and the clays still plastic. The diagenetic maturation of the organic material indicates that the sediments have been buried to a depth of about 1100-1300 m, and later uplifted to their present position, probably partly during Late Cretaceous - Paleocene inversion and partly during the post-Eocene regional uplift of parts of Scandinavia.

The detrital kaolinite exhibits a greater thermal stability (increasing down-section) than that expected in kaolinite at depths between 100 and $300 \mathrm{~m}$. It is believed that the increased thermal stability was reached during progressive diagenesis, resulting from burial to a depth of $1200-1400 \mathrm{~m}$. The progressive diagenesis did not reach the stage of complete illitisation of the original detrital smectite minerals.

The lowermost part of the section, member F-III of the Fjerritslev Formation, was deposited in a storminfluenced, marine, well-oxygenated environment. The influence of storms decreased somewhat in the latest Pliensbachian and earliest Toarcian, and the bottom conditions became more oxygen-deficient. Throughout the remaining part of the Toarcian, anoxic conditions prevailed and the environment shallowed progressively, probably due to localised, marginal high sedimentation rates despite the regional relative sea-level rise. 
Deltaic environments dominated in latest Toarcian Aalenian times, represented by the uppermost part of member F-III and member F-IV of the Fjerritslev Formation. The Bajocian/Bathonian Haldager Sand Formation is interpreted as a delta-plain deposit.

\section{Acknowledgements}

We thank Henrik Friis for critically reading the manuscript, Jette Gissel Nielsen who processed the foraminiferal samples and drafted some of the illustrations, Bitten Larsen and Yvonne Desezar for processing the palynological samples, and Ulla Bjerring, Jette Grejs Pedersen, Bente Winsløv Jensen and Terese K. Rasmussen for performing the sediment-analysis. Lis Olesen is thanked for drafting assistance. This work was supported by the Danish Natural Science Research Council (GEOKAT and MAGKAT projects and an Ole Rømer stipendium to M.-S.S.) and the Carlsberg Foundation.

\section{References}

Abrahamsen, N. 1992: On farsidedness of palaeomagnetic poles: magnetic refraction, sediment compaction, and dipole off-set. Studia Geophysica et Geodaetica 36, 26-41.

Abrahamsen, N. 1994: Magnetostratigraphy of the Tertiary Harre core, Denmark. Aarhus Geoscience 1, 53-64.

Ali, J.R., Heilmann-Clausen, C., Thomsen, E. \& Abrahamsen, N. 1994: Magnetostratigraphy of the type Selandian: preliminary results. Geologiska Föreningens i Stockholm Förhandlingar 116, 43 only.

Bang, I. 1968a: Biostratigrafisk analyse af kerneprøver fra Øresundsboringerne sommeren 1964 på grundlag af foraminiferer. In: Larsen, G. et al. (eds): Øresund; Helsingør-Hälsingborg Linien; Geologisk rapport. Danmarks Geologiske Undersøgelse Rapport 1, 63-71.

Bang, I. 1968b: Biostratigraphical investigations of the preQuaternary in the Øresund boreholes mainly on the basis of foraminifera. In: Larsen, G. et al. (eds): Øresund; HelsingørHälsingborg Linien; Geologisk rapport. Danmarks Geologiske Undersøgelse Rapport 1, 86-88.

Bang, I. 1971: Jura aflejringerne i Rønde nr. 1 (2103-2614 m), biostratigrafi på grundlag af foraminiferer. In: Rasmussen, L.B. (ed.): Dybdeboringen Rønde nr. 1 på Djursland. Danmarks Geologiske Undersøgelse III. Række 39, 74-80.

Bang, I. 1973: Jura-biostratigrafi i Nøvling nr. 1 på grundlag af foraminiferer. In: Rasmussen, L.B. (ed.): Dybdeboringen Nøvling nr. 1 i Midtjylland. Danmarks Geologiske Undersøgelse III. Række 40, 119-123.

Bertelsen, F. 1979: Palynological investigations of the TriassicJurassic section of the Hobro No. 1 borehole. In: Michelsen, O. (ed.): Report on the Jurassic of the Hobro No. 1 and Voldum
No. 1 borings, Denmark. Danmarks Geologiske Undersøgelse Årbog 1978, 141-149.

Burtner, R.L. \& Warner, M.A. 1986: Relationship between illite/smectite diagenesis and hydrocarbon generation in Lower Cretaceous Mowry and Skull Creek Shales of the northern Rocky Mountain area. Clays and Clay Minerals 34, 390-402.

Clausen, J. 1982: En kulpetrografisk og mineralogisk undersøgelse af Mesozoiske sedimenters termale modenhed og diagenesegrad i boringen Dansk Nords $\varnothing$ J-1, 115 pp. Unpublished cand. scient. thesis, Aarhus Universitet, Danmark

Conner, D.C. \& Kelland, D.G. 1975a: How Oxy's log program evaluated Piper Reservoir. Part 1. Oil and Gas Journal 73, 98-101.

Conner, D.C. \& Kelland, D.G. 1975b: How Oxy's log program evaluated Piper Reservoir. Part 2. Oil and Gas Journal 73, 152-160.

Dunoyer de Segonzac, G. 1970: The transformation of clay minerals during diagenesis and low grade metamorphism. A review. Sedimentology 15, 281-346.

Dybkjær, K. 1988: Palynological zonation and stratigraphy of the Jurassic section in the Gassum No. 1-borehole, Denmark. Danmarks Geologiske Undersøgelse Serie A 21, 73 pp.

Dybkjær, K. 1991: Palynological zonation and palynofacies investigation of the Lower to lowermost Middle Jurassic Fjerritslev Formation in the Danish Subbasin. Danmarks Geologiske Undersøgelse Serie A 30, 150 pp.

Gradstein, F.M., Agterberg, F.P., Ogg, J.G., Hardenbol, J., van Veen, P., Thierry, J. \& Huang, Z. 1994: A Mesozoic time scale. Journal of Geophysical Research 99, 24051-24074.

Hallam, A. 1988: A reevaluation of Jurassic eustasy in the light of new data and the revised Exxon curve. In: Wilgus, C.K. et al. (eds): Sea-level changes - an integrated approach. Society of Economic Paleontologists and Mineralogists Special Publication 42, 261-273.

Hansen, A.B. \& Thomsen, E. 1990: Biomarkers: molecular indicators of source rock maturity. Examples from the Danish Central Trough. In: Balling, N. et al. (eds): Proceedings of Basin Workshop, Aarhus 1989. GeoSkrifter 35, 109-115.

Harland, W.B., Armstrong, R.L., Cox, A.V., Craig, L.E., Smith, A.G. \& Smith, D.G. 1990: A geologic time scale 1989, 263 pp. Cambridge: Cambridge University Press.

Hoelstad, T. 1985: Palynology of the uppermost Lower to Middle Jurassic strata on Bornholm, Denmark. Bulletin of the Geological Society of Denmark 34, 111-132.

Holdridge, D.A. \& Vaughan, F. 1957: The kaolin minerals (kandites). In: Mackenzie, R.C. (ed.): The differential thermal investigation of clays, 98-139. London: Mineralogical Society.

Japsen, P. 1992: Landhæuningerne i Sen Kridt og Tertiær i det nordlige Danmark. Dansk Geologisk Forening Årsskrift for 1990-91, 169-182.

Japsen, P. 1993: Influence of lithology and Neogene uplift on seismic velocities in Denmark: implications for depth conversions of maps. American Association of Petroleum Geologists Bulletin 77, 194-211.

Jensen, L.N. \& Michelsen, O. 1992: Tertiær hævning og erosion i Skagerrak, Nordjylland og Kattegat. Dansk Geologisk Forening Årsskrift for 1990-91, 159-168.

Jensen, L.N. \& Schmidt, B.J. 1992: Late Tertiary uplift and erosion in the Skagerrak area: magnitude and consequences. 
Norsk Geologisk Tidsskrift 72, 275-279.

Jensen, L.N. \& Schmidt, B.J. 1993: Neogene uplift and erosion offshore south Norway: magnitude and consequences for hydrocarbon exploration in the Farsund Basin. In: Spencer, A.M. (ed.): Generation, accumulation and production of Europe's hydrocarbons. III. European Association of Petroleum Geoscientists Special Publication 3, 79-88.

Koch, J.-O. 1983: Sedimentology of Middle and Upper Jurassic sandstone reservoirs of Denmark. Geologie en Mijnbouw 16, 115-129.

Koppelhus, E.B. \& Batten, D.J. 1996: Applications of a palynomorph zonation to a series of short borehole sections, Lower to Middle Jurassic, Øresund, Denmark. In: Jansonius, J. \& McGregor, D.C. (eds): Palynology: principles and applications. American Association of Stratigraphic Palynologists Foundation 2, 779-793.

Koppelhus, E.B. \& Dam, G. 2003: Palynostratigraphy and palaeoenvironments of the Rævekløft, Gule Horn and Ostreaelv Formations (Lower-Middle Jurassic), Neill Klinter Group, Jameson Land, East Greenland. In: Ineson, J.R. \& Surlyk, F. (eds): The Jurassic of Denmark and Greenland. Geological Survey of Denmark and Greenland Bulletin 1, 723-775 (this volume).

Koppelhus, E.B. \& Nielsen, L.H. 1994: Palynostratigraphy and palaeoenvironments of the Lower to Middle Jurassic Baga Formation of Bornholm, Denmark. Palynology 18, 139-194.

Korsbech, U. 1992: SNG-logs og kernemålinger for boringer ved Skagen, 34 pp. Unpublished report, BHR-69, Afdelingen for Elektrofysik, Danmarks Tekniske Højskole, Lyngby, Danmark.

Korsbech, U. \& Nielsen, K.G. 1991: SNG-logs i dybe vandboringer i Sønderjylland, 29 pp. Unpublished report, BHR-64, Afdelingen for Elektrofysik, Danmarks Tekniske Højskole, Lyngby, Danmark.

Krabbe, H. 1986: En sedimentologisk (mineralogisk og organokemisk) undersøgelse af Rhæt-Jura-Nedre Kridt intervallet i boring Års-1a, 179 pp. Unpublished cand. scient. thesis, Aarhus Universitet, Danmark.

Larsen, G. 1966: Rhaetic-Jurassic-Lower Cretaceous sediments in the Danish Embayment. (A heavy-mineral study). Danmarks Geologiske Undersøgelse II. Række 91, 127 pp.

Liboriussen, J., Ashton, P. \& Tygesen, T. 1987: The tectonic evolution of the Fennoscandian Border Zone in Denmark. In: Ziegler, P.A. (ed.): Compressional intra-plate deformations in the Alpine Foreland. Tectonophysics 137, 21-29.

Lindgreen, H. 1991: Elemental and structural changes in illite/smectite mixed-layer clay minerals during diagenesis in Kimmeridgian-Volgian (-Ryazanian) clays in the Central Trough, North Sea and the Norwegian-Danish Basin. Bulletin of the Geological Society of Denmark 39, $82 \mathrm{pp}$.

Løfaldli, M. \& Nagy, J. 1980: Foraminiferal stratigraphy of Jurassic deposits on Kongsøya, Svalbard. Norsk Polarinstitutt Skrifter 172, 63-95.

Lund, J.J. 1977: Rhaetic to lower Liassic palynology of the onshore south-eastern North Sea Basin. Danmarks Geologiske Undersøgelse II. Række 109, 129 pp.

Lykke-Andersen, H., Seidenkrantz, M.-S. \& Knudsen, K.L. 1993: Quaternary sequences and their relations to the pre-Quaternary in the vicinity of Anholt, Kattegat, Scandinavia. Boreas 22, 291-298.
Meldgaard, S. \& Knudsen, K.L. 1979: Metoder til indsamling og oparbejdning af prøver til foraminifer-analyser. Dansk NaturDansk Skole Årsskrift 1979, 48-57.

Michelsen, O. 1978: Stratigraphy and distribution of Jurassic deposits of the Norwegian-Danish Basin. Danmarks Geologiske Undersøgelse Serie B 2, 28 pp.

Michelsen, O. 1989a: Log-sequence analysis and environmental aspects of the Lower Jurassic Fjerritslev Formation in the Danish Subbasin. Danmarks Geologiske Undersøgelse Serie A 25, 23 pp.

Michelsen, O. 1989b: Revision of the Jurassic lithostratigraphy of the Danish Subbasin. Danmarks Geologiske Undersøgelse Serie A 24, 22 pp.

Michelsen, O. \& Nielsen, L.H. 1991: Well records on the Phanerozoic stratigraphy in the Fennoscandian Border Zone, Denmark. Hans-1, Sæby-1, and Terne-1 wells. Danmarks Geologiske Undersøgelse Serie A 29, 37 pp.

Michelsen, O., Nielsen, L.H., Johannessen, P.N., Andsbjerg, J. \& Surlyk, F. 2003: Jurassic lithostratigraphy and stratigraphic development onshore and offshore Denmark. In: Ineson, J.R. \& Surlyk, F. (eds): The Jurassic of Denmark and Greenland. Geological Survey of Denmark and Greenland Bulletin 1, 147-216 (this volume).

Nagy, J. 1992: Environmental significance of foraminiferal morphogroups in Jurassic North Sea deltas. Palaeogeography, Palaeoclimatology, Palaeoecology 95, 111-134.

Nagy, J. \& Seidenkrantz, M.-S. in press: New foraminiferal taxa and revised biostratigraphy of Jurassic marginal marine deposits on Anholt, Denmark. Micropaleontology 49

Nagy, J., Dypvik, H. \& Bjaerke, T. 1984: Sedimentological and paleontological analyses of Jurassic North Sea deposits from deltaic environments. Journal of Petroleum Geology 7, 169-188.

Nagy, J., Løfaldli, M. \& Bäckström, S.A. 1988: Aspects of foraminiferal distribution and depositional conditions in Middle Jurassic to Early Cretaceous shales in eastern Spitzbergen. In: Rögl, F. \& Gradstein, F.M. (eds): 2nd Workshop on agglutinated foraminifera. Abhandlungen der Geologischen Bundesanstalt Wien 30, 287-300.

Nagy, J., Pilskog, B. \& Wilhelmsen, R.M. 1990: Facies-controlled distribution of foraminifera in the Jurassic North Sea Basin. In: Hemleben, C. et al. (eds): Paleoecology, biostratigraphy, paleoceanography and taxonomy of agglutinated foraminifera, 621-657. Dordrecht: Kluwer Academic Publishers.

Nagy, J., Gradstein, F.M., Gibling, M.R. \& Thomas, F.C. 1995: Foraminiferal stratigraphy and paleoenvironments of Late Jurassic to Early Cretaceous deposits in Thakkhola, Nepal. Micropaleontology 41, 143-170.

Nielsen, B.L. \& Friis, H. 1985: Diagenesis of Middle Jurassic Haldager Formation sandstone in the Danish Subbasin, north Jutland. Bulletin of the Geological Society of Denmark 33, 273-285.

Nielsen, O.B. 1979: Undersøgelse af jurassiske sedimenter i Centralgraben, Nordsøen, Boring U-1, 16 pp. Unpublished report, Geologisk Institut, Aarhus Universitet, Danmark.

Nielsen, O.B. 1992: Lithologi, lithostratigrafi og aflejringsmiljø i Anholtboringen. Dansk Geologisk Forening Årsskrift for 1990-91, 67-72.

Nielsen, O.B., Cremer, M., Stein, R., Thiébault, F. \& Zimmerman, 
H. 1989: Analysis of sedimentary facies, clay mineralogy, and geochemistry of the Paleogene sediments of Site 647, Labrador Sea. In: Srivastava, S.P. et al. (eds): Proceedings of the Ocean Drilling Program, Scientific Results 105, 101-110.

Nielsen, S. 1985: Aflejringsmiljø og lerdiagenese i Det danske

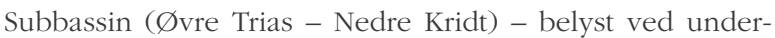
søgelse af cuttings fra Dansk Nordsø F-1 og boring 11/10-1, 154 pp. Unpublished cand. scient. thesis, Aarhus Universitet, Danmark.

Norling, E. 1972: Jurassic stratigraphy and foraminifera of western Scania, southern Sweden. Sveriges Geologiska Undersökning Serie Ca 47, 120 pp.

Norton, F.H. 1939: Identification of clay minerals by D.T.A. Journal of the American Ceramic Society 22, 54-63.

Nørvang, A. 1957: The foraminifera of the Lias Series in Jutland, Denmark. Meddelelser fra Dansk Geologisk Forening 13, 275-413.

Ogg, J.G., Steiner, M.B., Oloriz, F. \& Tavera, J.M. 1984: Jurassic magnetostratigraphy, 1: Kimmeridgian-Tithonian of Sierra Gorda and Carcabuey, southern Spain. Earth and Planetary Science Letters 71, 147-162.

Pedersen, G.K. 1986: Changes in the bivalve assemblage of an early Jurassic mudstone sequence (the Fjerritslev Formation in the Gassum 1 well, Denmark). Palaeogeography, Palaeoclimatology, Palaeoecology 53, 139-168.

Petersen, H.I., Nielsen, L.H., Bidstrup, T. \& Thomsen, E. 2003: Burial depth and post-Early Cretaceous uplift of Lower-Middle Jurassic strata in the Fennoscandian Border Zone based on organic maturity. In: Ineson, J.R. \& Surlyk, F. (eds): The Jurassic of Denmark and Greenland. Geological Survey of Denmark and Greenland Bulletin 1, 611-630 (this volume).

Pevear, D.R., Williams, V.E. \& Mustoe, G. 1980: Kaolinite, smectite and K-rectorite in bentonites: relation to coal rank at Tulameen, British Columbia. Clays and Clay Minerals 28, 241-254.

Poulsen, N.E., Gudmundson, L., Hansen, J.M. \& Husfelt, Y. 1990: Palynological preparation techniques, a new Macerationtankmethod and other modifications. Danmarks Geologiske Undersøgelse Serie C 10, 22 pp.

Press, F. \& Siever, R. 1982: Earth, 3rd edition, 613 pp. San Francisco: W.H. Freeman \& Co.

Riding, J.B. \& Thomas, J.E. 1992: Dinoflagellate cysts of the Jurassic System. In: Powell, A.J. (ed.): A stratigraphic index of dinoflagellate cysts, 7-97. British Micropalaeontological Society Publication Series. London: Chapman \& Hall.

Schmidt, B.J. 1985a: Clay mineral investigations of the Rhaetic Jurassic - Lower Cretaceous sediments of the Børglum-1 and Uglev-1 wells, Denmark. Bulletin of the Geological Society of Denmark 34, 97-110.

Schmidt, B.J. 1985b: A coal petrographic source rock evaluation of the Rhaetic - Jurassic - Lower Cretaceous sediments of the Børglum-1 and Uglev-1 wells, Denmark. Bulletin of the Geological Society of Denmark 33, 239-252.

Schmidt, B.J. 1989: Maturity and source rock evaluation of the
Mesozoic sequence in some Danish off-shore wells outside the Central Trough, 429 pp. Unpublished Ph.D. thesis, Aarhus University, Denmark.

Schmidt, B.J. 1990: Use of vitrinite reflectance in basin studies. In: Balling, N. et al. (eds): Proceedings of Basin Workshop, Aarhus 1989. GeoSkrifter 35, 117-119.

Schulz, E. 1967: Sporenpaläontologische Untersuchungen zur Rhät-Lias-Grenze in Thüringen und der Altmark. Geologie 11(3), 308-320.

Seidenkrantz, M.-S., Koppelhus, E.B. \& Ravn-Sørensen, H. 1993: Biostratigraphy and palaeoenvironmental analysis of a Lower to Middle Jurassic succession on Anholt, Denmark. Journal of Micropalaeontology 12, 201-218.

Sorgenfrei, T. \& Buch, A. 1964. Deep tests in Denmark, 1935-1959. Danmarks Geologiske Undersøgelse III. Række 36, 146 pp.

Środoń, J. \& Eberl, D.D. 1984: Illite. In: Bailey, S.W. (ed.): Micas. Reviews in Mineralogy 13, 495-544. Washington DC: Mineralogical Society of America.

Steiner, M.B., Ogg, J.G., Melendez, G. \& Sequeiros, L. 1985: Jurassic magnetostratigraphy, 2: Middle-Late Oxfordian of Aguilon, Iberian Cordillera, northern Spain. Earth and Planetary Science Letters 76, 151-166.

Steiner, M.B., Ogg, J.G. \& Sandoval, J. 1987: Jurassic magnetostratigraphy, 3: Bathonian-Bajocian of Carcabuey, Sierra Harana and Campillo de Arenas (Subbetic Cordillera, southern Spain). Earth and Planetary Science Letters 82, 357-372.

Strømnes, E. 1991: Kvantifisering av tertiær oppløft og erosion i en travers over Egersundbassenget, 71 pp. Unpublished thesis, Norges Tekniske Høgskole, Trondheim, Norge.

Teichmüller, M. \& Teichmüller, R. 1979: Diagenesis of coal (coalification). In: Larsen, G. \& Chilingar, R.V. (eds): Diagenesis of sediments and sedimentary rocks, 207-246. Amsterdam: Elsevier.

Ter-Borch, N. 1987: Structural map of the Top Chalk Group, 1:500 000. Hørsholm, Denmark: Skov- og Naturstyrelsen, Havbundsundersøgelsen og Dansk Olie- \& Gasproduktion A/S. (Also distributed as Ter-Borch, N. 1991: Geologisk kort over Danmark, 1:500 000. Kalkoverfladens struktur. Danmarks Geologiske Undersøgelse Kortserie 7, 4 pp, 1 map.)

Thomsen, E., Damtoft, K. \& Andersen, C. 1987: Hydrocarbon plays in Denmark outside the Central Trough. In: Brooks, J. \& Glennie, K.W. (eds): Petroleum geology of North West Europe, 375-388. London: Graham \& Trotman.

Tissot, B.P., Pelet, R. \& Ungerer, P. 1987: Thermal history of sedimentary basins, maturation indices and kinetics of oil and gas generation. American Association of Petroleum Geologists Bulletin 71, 1445-1466.

Waples, D.W. 1985: Geochemistry in petroleum exploration, 232 pp. Boston: International Human Resources Development Corporation.

Woollam, R. \& Riding, J.B. 1983: Dinoflagellate cyst zonation of the English Jurassic. Institute of Geological Sciences Report 83/2, 42 pp. London: Her Majesty's Stationery Office. 
